\title{
Impact of Agrochemicals on Soil Microbiota and Management: A Review
}

\author{
Ram Swaroop Meena ${ }^{1,2} \mathbb{0}$, Sandeep Kumar ${ }^{3}$, Rahul Datta ${ }^{4, *}$, Rattan Lal ${ }^{2}$, \\ Vinod Vijayakumar ${ }^{5}$ (D), Martin Brtnicky ${ }^{4}$, Mahaveer Prasad Sharma ${ }^{6}$, Gulab Singh Yadav ${ }^{2,7}$, \\ Manoj Kumar Jhariya ${ }^{8}$ D, Chetan Kumar Jangir ${ }^{3}$, Shamina Imran Pathan ${ }^{9}$, Tereza Dokulilova ${ }^{4}$, \\ Vaclav Pecina ${ }^{4}$ and Theodore Danso Marfo ${ }^{10}$ (D) \\ 1 Department of Agronomy, Institute of Agricultural Sciences, Banaras Hindu University, Varanasi 221 005, \\ India; meenars@bhu.ac.in \\ 2 Carbon Management and Sequestration Centre, The Ohio State University, Columbus, OH 43210, USA; \\ lal.1@osu.edu (R.L.); gs.yadav1@icar.gov.in (G.S.Y.) \\ 3 ICAR-National Academy of Agricultural Research Management (NAARM), Hyderabad 500030, India; \\ sandeepsihag1992@naarm.org.in (S.K.); chetanjangir710@naarm.org.in (C.K.J.) \\ 4 Department of Agrochemistry, Soil Science, Microbiology and Plant Nutrition, Faculty of Agrisciences, \\ Mendel University in Brno, Zemedelska 1, Brno 61300, Czech Republic; martin.brtnicky@mendelu.cz (M.B.); \\ tereza.dokulilova@mendelu.cz (T.D.); vaclav.pecina@mendelu.cz (V.P.) \\ 5 College of Food, Agricultural, and Environmental Sciences, The Ohio State University, Columbus, OH 43210, \\ USA; vinod.vjkumar@gmail.com \\ 6 Microbiology Laboratory, ICAR-Indian Institute of Soybean Research, Khandwa Road, Indore (MP) 452001, \\ India; mahaveer.sharma@icar.gov.in \\ 7 ICAR Research Complex for NEH Region, Lembucherra 799210, India \\ 8 Department of Farm Forestry, University Teaching Department, Sant Gahira Guru \\ Vishwavidyalaya (Formerly, Sarguja University), Sarguja, Ambikapur 497001, India; manu9589@gmail.com \\ 9 Department of Agri-food, environmental, Forestry Science and Technology (DAGRI), University of Florence, \\ Piazzale delle Cascine 28, 50144 Florence, Italy; shamina.pathan@unifi.it \\ 10 Department of Geology and Pedology, Mendel University in Brno, Zemedelska 1, Brno 61300, \\ Czech Republic; xmarfo@mendelu.cz \\ * Correspondence: rahul.datta@mendelu.cz; Tel.: +420-773-990-283
}

Received: 31 December 2019; Accepted: 17 January 2020; Published: 23 January 2020

check for updates

\begin{abstract}
The World Health Organization (WHO) states that in developing nations, there are three million cases of agrochemical poisoning. The prolonged intensive and indiscriminate use of agrochemicals adversely affected the soil biodiversity, agricultural sustainability, and food safety, bringing in long-term harmful effects on nutritional security, human and animal health. Most of the agrochemicals negatively affect soil microbial functions and biochemical processes. The alteration in diversity and composition of the beneficial microbial community can be unfavorable to plant growth and development either by reducing nutrient availability or by increasing disease incidence. Currently, there is a need for qualitative, innovative, and demand-driven research in soil science, especially in developing countries for facilitating of high-quality eco-friendly research by creating a conducive and trustworthy work atmosphere, thereby rewarding productivity and merits. Hence, we reviewed (1) the impact of various agrochemicals on the soil microbial diversity and environment; (2) the importance of smallholder farmers for sustainable crop protection and enhancement solutions, and (3) management strategies that serve the scientific community, policymakers, and land managers in integrating soil enhancement and sustainability practices in smallholder farming households. The current review provides an improved understanding of agricultural soil management for food and nutritional security.
\end{abstract}

Keywords: agrochemicals; pesticide; insecticide; fungicide 


\section{Introduction}

In many developing nations, current agricultural methods follow unsustainable practices which have resulted in a huge amount of toxic effluents being emitted directly or indirectly into the soil, air, and water [1]. The advent of nanotechnology and nanomaterials has further complicated the scenario of soil inputs and their degradation [2,3]. The element of variation in soil properties based on climatic and geospatial characteristics are also crucial for consideration [4,5]. Currently, various agrochemicals (i.e., herbicides, fungicides, insecticides, nematicides, molluscicides, rodenticides, chemical fertilizers are being used non-judiciously [6] which have adversely affected beneficial soil (micro) biota (Figure 1).

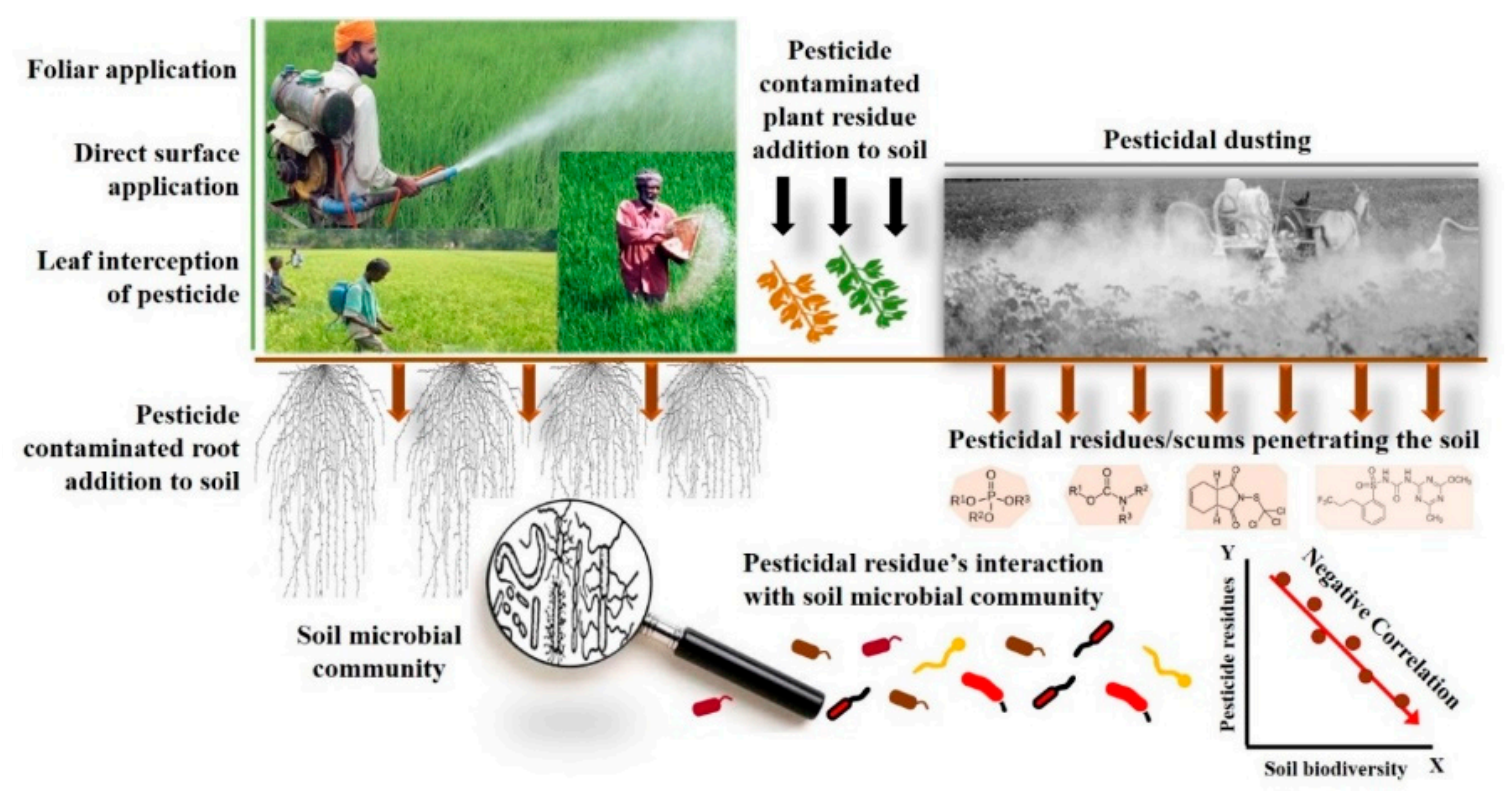

Figure 1. A schematic illustration depicting the response and effects of pesticides on soil microbial communities and biodiversity.

Any substance used to control, repel, or kill plant or animal life is a pesticide, and the group includes herbicides, insecticides, and fungicides. There is a constantly increasing demand for pesticides, and more than $50 \%$ of the pesticides used are from Asia (Figure 2). Saint Lucia is at the top among per hectare usage of pesticides (Figure 3) and China is at the top when it comes to most pesticide-consuming countries in the world (Figure 4). The increasing global demand for quality protein-rich food resources for an ever-increasing world population entitles a pressing need for the development of an ecologically sound strategy for sustaining soil health and advancing food security without degrading soil biodiversity on a global.

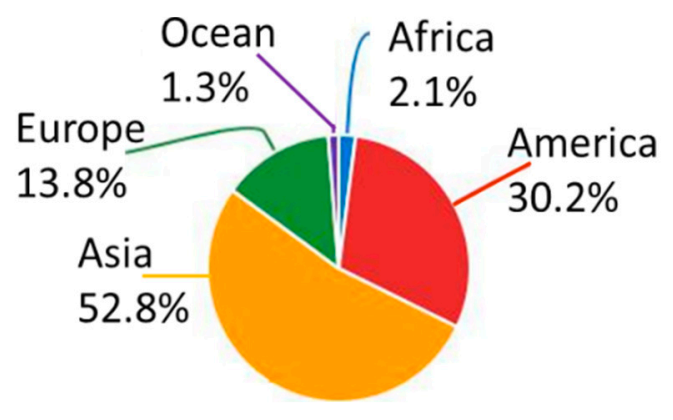

Figure 2. Percentage share of pesticide use by different continent. Source (FAO) [7]. 


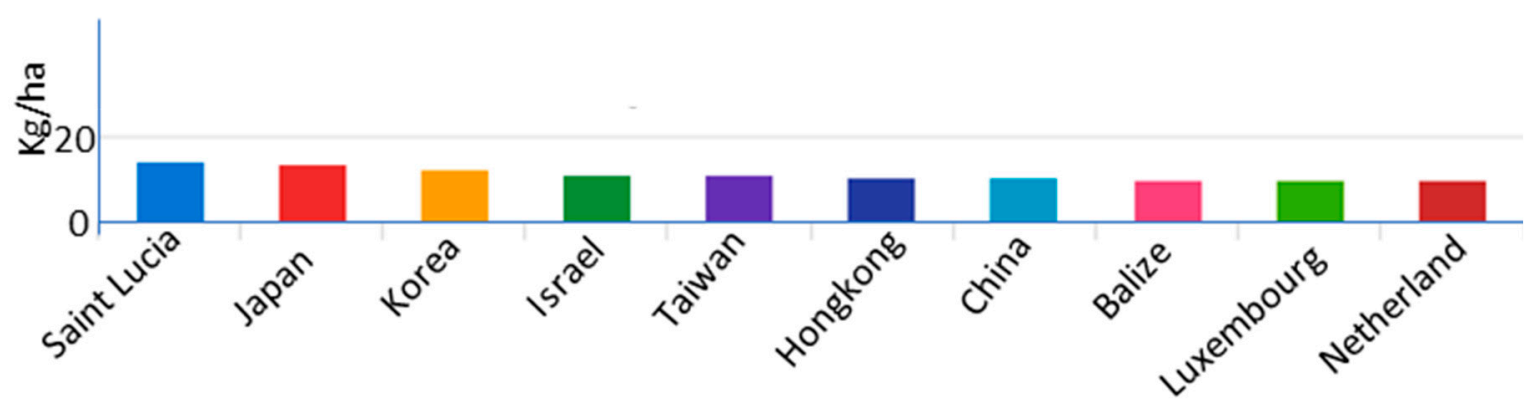

Figure 3. World top ten pesticide consuming countries in $\mathrm{kg} / \mathrm{ha}$. Source (FAO) [7].

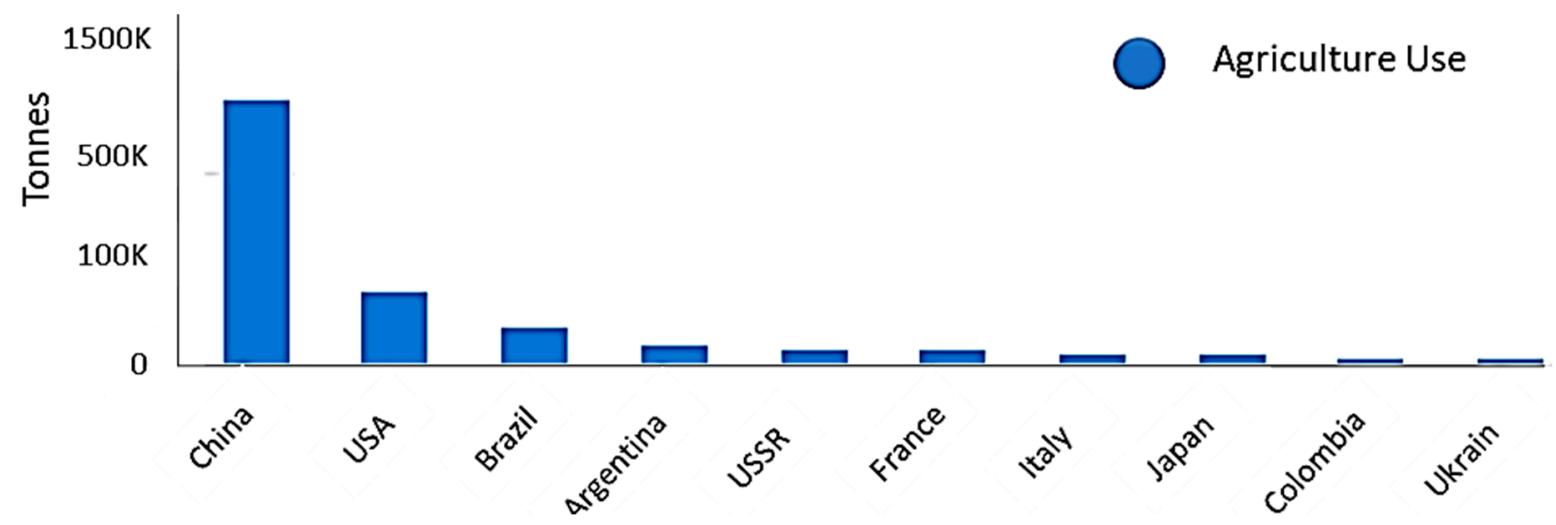

Figure 4. World top ten pesticide using countries. Source (FAO) [7].

Impact of pesticides on agronomic yield and profit margin makes them a significant component of modern agricultural practices. However, the indiscriminate use of pesticides leads to the degradation of soil's microbial ecosystems [8]. Weeds and insects are the major reducing biotic factors in agriculture and hamper crop yield, productivity, and resource use efficiency [9]. Therefore, herbicides (type of pesticide that kills specifically targeted herbs) and insecticides (type of pesticide that kills specifically targeted insects) are being used indiscriminately for ensuring higher production by eliminating or suppressing pest population [10]. The United States is first among the top ten herbicide- and insecticide-using countries in the world (Figures 5 and 6). The cost of labor, choice of pesticide application, and the promise of swift pest control have made the use of pesticides judicial or rampant all over the world [11]. These chemical compounds are either applied directly to the soil strata or as a spray, where drifting sprays and excessive inputs through leaching enters rivers, streams and other water bodies as agricultural run-offs [12].

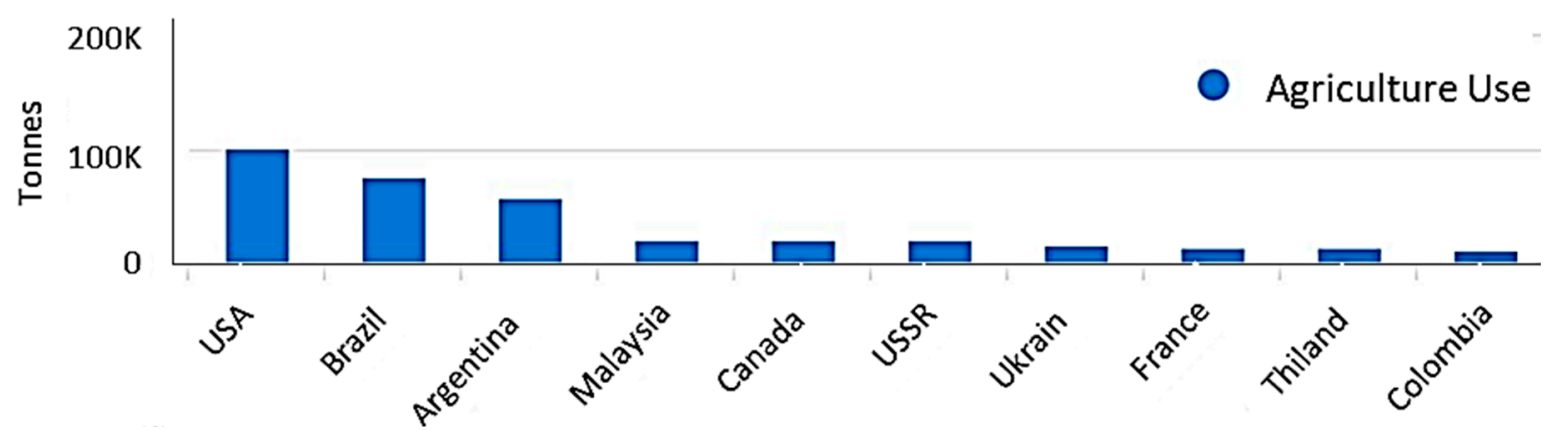

Figure 5. World top ten herbicide using countries. Source (FAO) [7]. 


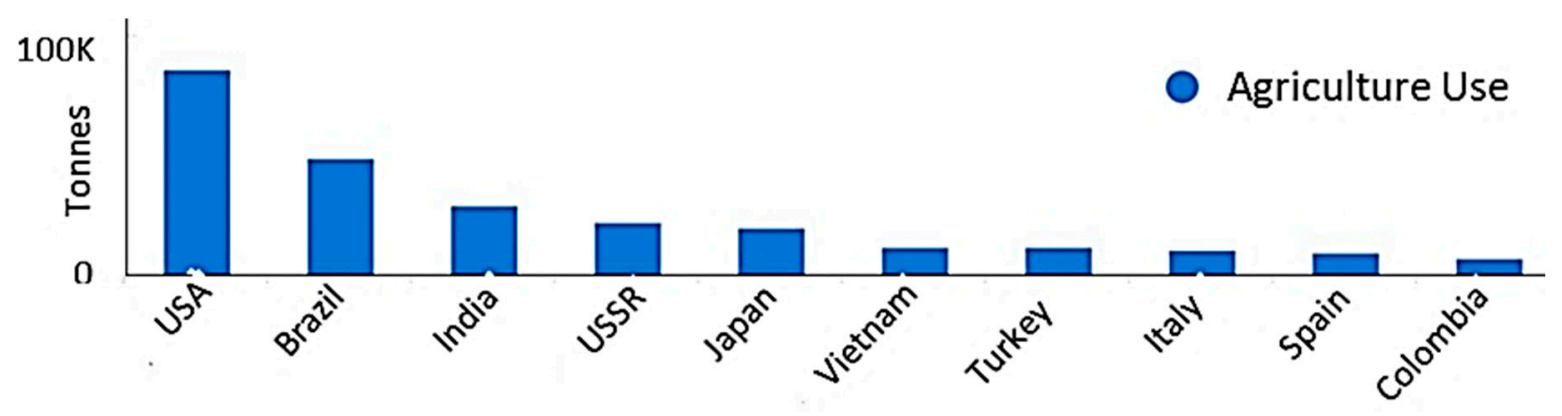

Figure 6. World top ten insecticide using countries. Source (FAO) [7].

Consequently, the soil receives the bulk of complex agrochemical compounds, several of which are poisonous to the activity of non-target beneficial soil micro-organisms [13]. More than $95 \%$ of the applied herbicides and $98 \%$ of insecticides reach non-target soil micro-organisms than their target pest, as they are sprayed proportionately across the entire field, irrespective of the affected areas [14]. Hence, of the total quantity of applied pesticides, about $0.1 \%$ reaches the target organisms while the remaining quantity pollutes the soil and environment. This indiscriminate use of pesticides not only disturbs the soil biodiversity but also adversely affects soil microcosms comprising of soil micro-fauna in field communities and soil ecosystem [15]. Large quantities of pesticides reaching to the soil have a direct effect on soil microbiota, which is a biological indicator of soil fertility influencing plant growth and development [16-18]. Similarly, several studies have reported the impact of numerous pesticides on subduing soil enzyme activity(s) which affects the nutrient status of soil and include hydrolyzes, nitrate reductase, urease, oxidoreductases, nitrogenase, and dehydrogenase activities. Further, biological nitrogen fixation (BNF) and their associated biotransformation (i.e., ammonification, nitrification, denitrification, phosphorus solubilization and S-oxidation) are also affected by pesticide applications [19]. In addition, reduced microbial carbon biomass (MCB) and functional diversities of many non-target soil microbial populations are affected because of intensive applications of pesticide in contemporary agriculture [13].

Elaine Ingham, American microbiologist and founder of Soil Foodweb, stated, "If we lose both bacteria and fungi, then the soil degrades". Microorganisms in the soil are exclusively important because they impact soil structure, functions, and fertility [20]. These organisms are primarily decomposers of organic matter, but also perform many other functions such as provide nitrogen $(\mathrm{N})$, phosphorus $(\mathrm{P})$, potassium $(\mathrm{K})$, etc., through fixation and mineralization. Thereby helping plants grow, detoxify harmful chemicals, suppress disease-causing organisms, and produce substances that may stimulate plant growth. Soil microbes also mineralize the essential plant nutrients in the soil to improve crop productivity, produce plant hormones that stimulate plant immune system, encourage growth, and activate stress responses [21]. For example, Rhizobium converts the atmospheric elemental N into biology. Factors comprising both above and below-ground biodiversity and population dynamics drive soil health. On a global scale, renewed efforts and focus on management strategies for food supply and security, nutrition, health, and soil sustainability are mandated for understanding the impact of agrochemicals on soil microbiota.

The overarching aim of this review is to provide a general overview of the impact of agrochemicals on soil sustainability and health and to outline some management options that may be useful to the scientific community, policymakers, and land managers in integrating sustainable farming practices with organic farming.

\section{Methodology}

This study represents the existing literature on the use and management of different agrochemicals. This article tries to improve the understanding of agricultural soil management for food and nutritional security. The literature review utilized for this paper was mainly qualitative in nature. We used keyword 
research in popular databases such as Google Scholar, Scopus and PubMed. The keywords used were agrochemical, pesticide, herbicide, insecticide, pesticide and soil biochemistry. Only articles published in English and from reputed journals from individual fields (Q1 and Q2 ranking journals from individual field based on scimago ranking) were considered. A sum of 148 publications was included. Major benchmark studies from 2000 to 2019 were selected to follow the progress in the field across the globe.

\section{Herbicides and Soil Microbial Environment}

\subsection{Impacts of Herbicides on Soil Biota}

Herbicides show a reduction in the total microbial population within 7 to 30 days after application depending on the type of herbicidal molecules [22] and adversely affect the microbial biodiversity indirectly by altering the physiology or biosynthetic mechanisms [23]. This, in turn, affects soil enzymatic activity, cellular membrane composition, protein biosynthesis, and the amount of plant growth regulators (gibberellins synthesis, transportation of Indoleacetic Acid (IAA), ethylene concentration, etc.) [22]. The application of excessive and higher doses of herbicides has also been reported to result in the death of many sensitive microbes [22].

The detrimental effects of applied chemical herbicides on soil microbial diversity depend on the degradability, adsorption and desorption, bioavailability, bioactivity, persistence, concentration, and toxicity of agrochemicals along with soil factors such as texture, vegetation, tillage system, and organic matter $[18,24]$. The reduction in soil microbial functionaries is more under conventional tillage than in no-till (NT) system. Under conventional till (CT) system, the soil microbial biomass carbon $(\mathrm{MBC})$ and mycorrhizal colonization decrease after 12 days of application of herbicide fomesafen and mixtures of fluazifop- butyl + fomesafen [25]. Some microbial communities are more sensitive to the interaction effect of herbicides with other compounds than the use of a single herbicide, as is the case with butachlor when applied in combination with cadmium [18]. Other herbicides in combination with inorganic fertilizers and heavy metals [26-29] suppress the functions of soil microbes. Following the application, herbicides undergo physical and biochemical transformations and produce several secondary metabolites which are more lethal or persistent to non-target microbial communities. This is exemplified by the effect of 2,4-D and its metabolites on Burkholderiacepacia-a group of gram-negative bacteria [30]. The herbicidal action also depends on the type of formulation being used in addition to the active ingredient such as surfactant and solvent [18]. The addition of surfactant polyoxyethylene amine in glyphosate makes herbicide more toxic to the bacterium as compared to glyphosate acid alone [31]. The use of biochar as a soil amendment may counter the negative effects of herbicides on soil biota [32].

The soil type can also play a critical role in the herbicidal effect. The effect can be more severe in coarse-textured soils. For example, Khan et al. (2006) reported severe negative effects of herbicides on microbial association and vitality of chickpea in sandy clay loam soils [33]. The herbicidal molecules belonging to the triazines group are more hazardous when applied over a long time due to their residual effect and persistence in soil [22]. The repeated applications of atrazine can significantly reduce the intensity of soil microbes [34]. Similarly, atrazine and metolachlor can alter the biodiversity of different species of actinomycetes and bacteria in soil [34]. Glyphosate, a nonselective herbicide belonging to organophosphate group, can decrease the activity of phosphate enzyme up to 98\% [35]; inhibit growth and activity of soil biota [16], and have toxic effects on mycorrhizal fungi when tested under laboratory conditions. Different effects of the herbicidal application on soil microbial communities, enzymes, and biochemical reactions are presented in (Table 1). 
Table 1. Herbicides and their reported effects on soil microorganisms, enzymes, and biochemical reactions.

\begin{tabular}{|c|c|c|}
\hline Herbicides & Effects on Microorganism and Associated Process & References \\
\hline 2,4-D & Adversely affects the activities of Rhizobium sp. & [17] \\
\hline $2,4-\mathrm{D}$ & $\begin{array}{l}\text { Reduces nitrogenase, phosphatase and hydrogen } \\
\text { photoproduction activities of purple non-sulfur bacteria }\end{array}$ & [36] \\
\hline 2,4-D and 2,4,5-T & $\begin{array}{c}\text { Adversely affects node-expression disrupting plant } \\
\text { Rhizobium signalling. 2,4-D also reduces fixation by } \\
\text { blue-green algae and nitrifying process impacting } \\
\text { nitrosomonas and Nitrobacter sp. }\end{array}$ & [37] \\
\hline 2,4-Damine, Agroxone, and Atranex & $\begin{array}{l}\text { Inhibits activities of Rhizobium phaseoli and } \\
\text { Azotobacter vinelandii (most sensitive) }\end{array}$ & [17] \\
\hline 2,4-D, Bromoxynil, and Methomyl & Reduces $\mathrm{CH}_{4}$ oxidation to $\mathrm{CO}_{2}$ & [38] \\
\hline $\begin{array}{l}\text { Bensulfuron methyl and } \\
\text { Metsulfuron-methyl }\end{array}$ & Decreases N-mineralization & [39] \\
\hline $\begin{array}{l}\text { Bentazone, Prometryn, } \\
\text { Simazine, and Terbutryn }\end{array}$ & $\begin{array}{l}\text { Inhibits } \mathrm{N} \text {-fixation and decreases the number of } \\
\text { nodules and } \mathrm{N} \text { content overall }\end{array}$ & {$[40]$} \\
\hline Isoproturon, Triclopyr & $\begin{array}{l}\text { Adversely impacts nitrosomonas, Nitrobacter, urea } \\
\text { hydrolyzing bacteria, nitrate reductase activity and } \\
\text { growth of actinomycetes and fungi }\end{array}$ & [41] \\
\hline $\begin{array}{l}\text { Linuron, Terbutryn, and } \\
\text { Methabenzthiazuron }\end{array}$ & $\begin{array}{l}\text { Adversely impacts nitrogenase activity and } \\
\text { nodulation at the pre-emergence application }\end{array}$ & [33] \\
\hline Glyphosate & Suppresses phosphatase activity & [35] \\
\hline Glyphosate & Reduces the growth and activity of azotobacter & [16] \\
\hline Metribuzin & $\begin{array}{l}\text { At lower doses, no effects on AM fungi } \\
\text { in maize and barley are observed }\end{array}$ & [42] \\
\hline
\end{tabular}

\subsection{Impact of Herbicides on N-Fixing Microbes}

Several herbicides can alter the symbiotic association between legume plants and rhizobacteria and hinder the vital processes of N-fixation [40,43]. Herbicides may influence the nodulation and consequently the BNF in legumes either by disturbing rhizobacterial infection process or by affecting root fibers of the plants where infection and node formation occur. They may also affect the phytochemical signaling of Rhizobium needed for coordination and regulation of the key processes in BNF [18]. Some herbicides affect the morphology of the cell, resulting in the formation of pleomorphic cells [18]. Herbicides can reduce root nodulation, bacteroids, dry plant matter, nitrogenase activity and adenosine triphosphate (ATP) synthesis of Rhizobium and thus symbiotic N-fixation [22]. Use of herbicides in soybean can suppress the growth and activity of Bradyrhizobium. The growth of Bradyrhizobium japonicum is abridged due to the application of herbicides in soybean in vitro cultures, while nodulation is affected under controlled greenhouse conditions [44]. However, the growth of B. japonicum is not affected by chlorimuron ethyl in pure cultures even at 150 times higher concentration than the recommended field rates [45]. The commonly used triazines (i.e., terbutryn, simazine, prometryn, and bentazone) reduces the rhizobial functionaries at concentrations more than the recommended rate [40]. On the contrary, herbicides such as sethoxydim, alachlor, fluazifop-butyl, and metolachlor had no detrimental effect on BNF and soybean yields at the recommended field rates. However, the non-selective herbicides paraquat and glyphosate (due to the presence of ethylamine formulation) [46] can reduce the $\mathrm{N}$-fixation in soybean. Herbicide pendimethalin at $0.5-1.0 \mathrm{~kg} / \mathrm{ha}$ can slow down the process of Rhizobium symbiosis in crop plants [47]. The commonly used herbicide 2,4-D tends to reduce the growth and activity of blue-green algae (BGA), inhibits nitrification, and the BNF process by affecting the activity of Rhizobium $\mathrm{sp}$. in beans. The residues of 2,4-D are found in cell wall and cytosol of Rhizobium in significant amounts confirming its impact on rhizobacterial propagation [17].

Azotobacter is anaerobic, free-living soil microorganism that plays an important role in $\mathrm{N}$-cycling by fixing nitrogen. It is highly sensitive to herbicides, even for a short exposure of 7-14 days [22]. 
The extent of inhibition of activity, population, growth, and development of Azotobacter depends on the kind as well as the dosage of herbicidal molecules used [46]. In the field of soybean and sunflower treated with prometryne, the biological activity of Azotobacter and some other bacteria was strongly reduced after 28 days of herbicide application [48]. Herbicides 2,4-D, atranex, and agroxone inhibited the occurrence of Rhizobium phaseoli and Azotobacter vinelandii, and their population further decreased with increase in herbicide concentration. Similarly, in sugarbeet, dimethenamid and metolachlor application significantly reduced Azotobacter's population by $33 \%-50 \%$ at the rate of $1.7 \mathrm{~L} / \mathrm{ha}$ [48], use of dimethenamide by $2 \%$ and $18 \%$ at the rate of $1.6 \mathrm{~L} /$ ha compared with $1.4 \mathrm{~L} / \mathrm{ha}$ and the blend of flumetsulam + trifluralin by $2 \%$ at the rate of $2 \mathrm{~L} /$ ha compared with $1.7 \mathrm{~L} / \mathrm{ha}$ as recommended [48].

\subsection{Impact of Herbicides on Arbuscular Mycorrhizal Fungi}

Mycorrhizas are symbiotic associations between fungi and roots of higher plants that enhance the uptake of nutrients, especially $\mathrm{P}$, nitrate $\left(\mathrm{NO}_{3}\right)$, and ammonium $\left(\mathrm{NH}_{4}\right)$, and improve soil aggregate stability [49]. The herbicides oryzalin, trifluralin, and oxadiazon have a deleterious effect on spore germination and propagation of mycorrhizal species [50]. In contrast, oxyfluorfen and oxadiazon stimulate the microbial population significantly and can enhance the P availability in rice [51]. Glyphosate significantly decreases root mycorrhization by $40 \%$, soil arbuscular mycorrhizal fungal (AMF) spore biomass, vesicles, and propagules under greenhouse conditions [52]. Glyphosate can directly influence the active metabolite production in the plant with negative impacts on root colonization of AMF [53], and indirectly affect the intra-radical mycelium growth and arbuscular formation which regulates the AMF abundance [52]. In contrast, Pasaribu et al. (2013) [50] did not find any significant effects of glyphosate on AMF (Glomus mosseae), and thus the P inflow through mycorrhizal hyphae was significantly increased with the application. Pasaribu and colleagues also reported that increasing rates of alachlor application significantly reduced the numbers of spores, total and active infection intensity of internal hyphae of vesicular-arbuscular mycorrhizae.

The adverse impacts of herbicides prometryn and acetochlor on AMF and symbiosis at increasing rates from 0.1 to $10 \mathrm{mg} / \mathrm{L}$ are widely known, with prometryn being more toxic than acetochlor [49,50]. Sharma and Buyer (2015) [54] observed the adverse effects of herbicides on AMF live-biomass in terms of AM signature fatty acids 16:1 $\omega 5$ phospholipid fatty acid (PLFA) and 16:1 $\omega 5$ neutral lipid fatty acid (NLFA) representing hyphal biomass and spore population in soil respectively, as a measure of AM propagation and survivability. Zaller et al. (2014) [52] observed the effects of Roundup (glyphosate)

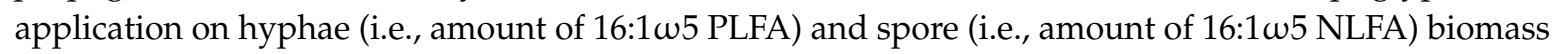
in the soil and found that spore biomass declined with herbicide application. Similar observations have been reported by Druille et al. (2013) [55], who showed that the spore germination is affected even at the lowest dose of glyphosate. While evaluating several biological pesticides along with chemical fungicides, Ipsilantis et al. (2012) [56] observed that application of pyrethrum, terpenes, and spinosad did not significantly affect the structure and root colonization ability of the AM fungal community. However, pots treated with carbendazim completely hampered mycorrhizal colonization. Gupta et al. (2011) [57] suggested that herbicidal application at higher concentrations should be resorted to only after careful consideration. While evaluating the impact of metribuzin herbicide on three species of AMF in maize and barley, Makarian et al. (2016) [42] reported that inoculation of AMF considerably improved the growth and chlorophyll content of barley and maize at lower herbicide concentrations (175 g a.i. ha ${ }^{-1}$ ) compared to non-inoculated treatments. Thus, it suggested that mycorrhizal fungi can alleviate crop stress under lower doses of metribuzin through increase in plant growth and advocated for avoiding the administration of higher doses. On the other hand, Sharma and Adholeya (2005) [54] found a positive effect of nematicide-carbofuran 3G (furadan) when applied in maize pot cultures and suggested their uses for cleaner maintenance of pot cultures. Thus, the effects of herbicides on AMF are case-dependent, and factors such as soil mineral composition, type of host, plant fitness and the nature of plant-fungal symbiotic interactions regarding reciprocal rewards may play a key role in determining the overall cause and effect [58]. It has also been reported that phenotypic plasticity 
governed by nutrient cycling and environmental factors, and plant-fungal phospholipid metabolism in AMS may lead to observed trait variations among different plant and AMF combinations in either agricultural or controlled environmental settings [59].

\subsection{Impact of Herbicides on Soil Biochemical and Enzymatic Environment}

Herbicides reduce several beneficial biochemical processes governed by soil microbes and enzymatic reactions that play a crucial role in maintaining or improving soil health [60]. Biochemical processes driven by soil microbes include mineralization, and associated bio-transformations like nutrient dynamics (nitrification, denitrification, and ammonification), redox reactions, methanogenesis, etc., are affected by exposure to herbicides [61]. The biochemical process of denitrification and nitrification are diminished in soils treated with prosulfuron even after $\mathrm{N}$ fertilization [60]. Herbicides also influence the soil enzymatic activities that influence "biological index" of soil fertility and biological functions in the soil profile [62]. Acetochlor and its derivatives are toxic to bacteria (i.e., fluorescens, Bacillus subtilis, and Mycobacterium phlei) that are involved in $\mathrm{N}$ transformations [63]. The herbicide, atrazine and simazine can completely arrest the growth, and biological action of Xanthobacter autotrophic when applied at the rate of $10 \mathrm{mg} / \mathrm{L}$ [64]. The herbicides alachlor and atrazine negatively affect the functioning of bacteria, those are needed for ammonification, and soil dehydrogenase activities at applications higher than the field recommended dose [65]. The impact on microbial activities varies with the mode of the herbicide application. For example, glyphosate applied in bunds can significantly diminish enzymatic activity but not when applied as granules. The herbicides atrazine and metolachlor can reduce the activity of invertase and dehydrogenase enzymes [35], respectively. However, chlorimuron-ethyl and furadan may enhance the activity of both these enzymes by $14 \%-18 \%$ and $13 \%-21 \%$, respectively [66,67].

\section{Fungicides and Soil Microbial Environment}

\subsection{Impact of Fungicides on N-Fixing and Growth-Promoting Microbes}

Most copper $(\mathrm{Cu})$ based fungicides have a deleterious effect on the population of N-fixing bacteria [68]. Fungicidal residues, for example, apron, arrest, captan, tend to remain in soil reacting with living organisms and affecting the $\mathrm{N}$-fixation in legume-Rhizobium association [69]. Both mancozeb and chlorothalonil can decrease the process of nitrification and denitrification at an incubation period of $\geq 48 \mathrm{~h}$ [60]. The negative impact of the long-term application of organomercurial Verdean on cellulolytic fungal species has also been reported [70]. Further, application of triarimol and captan can decrease the frequency of Aspergillus species responsible for plant growth and development. Carbendazim is moderately toxic to Pseudomonas fluorescens and Bacillus subtilis while being highly toxic to Trichoderma harzianum, a potent biocontrol agent active against soil-borne fungal phytopathogens (i.e., Fusarium, Pythium, and Rhizoctonia) on soybean, potato, cotton and other crops [63]. The impact of fungicides such as chlorothalonil and azoxystrobin on soil microbial activities, has long been recognized with negative effects on the biocontrol agents itself as in Fusarium wilt [71]. On the other hand, the inhibitory effect of fungicide applications on the activity of certain fungi has led to a fast flush of bacterial activity as well [13].

\subsection{Impacts of Fungicides on Soil Microbiota}

Several studies have reported the harmful effects on soil microbial growth, survival, and activity [72]. Fungicide bavistin has an inhibitory effect on several soil microbial populations, but the impact is non-significant [57]. AMF can be sensitive to some molecules of fungicides but not to all [73]. Benzoyl is responsible for the long-term reduction in mycorrhizal associations [74] with many fungicides being toxic to hyphal growth and thus root colonization of AMF associations of pea [72]. Emisan (holding 6\% 2-methoxyethylmercury chloride) and carbendazim (benzimidazole fungicide and a metabolite of benomyl) both have a damaging effect on AMF in groundnut. However, applications of $\mathrm{Cu}$ can provide a stimulus to mycorrhizae in groundnut. Applications of metalaxyl favor AM colonization 
in roots of soybeans and maize [66]. Murillo-Williams and Pedersen (2008) [75] reported that under non-fumigated soil conditions, seed-applied fungicides in combination with fludioxonil favors AM colonization due to a reduced competition from aggressive pathogens like Rhizoctonia spp., an organism that is the target of this fungicide. The impact of a wide range of fungicides on beneficial soil microbiota is depicted in Table 2.

Table 2. Fungicides and their impacts on beneficial processes of soil microbiota.

\begin{tabular}{|c|c|c|}
\hline Fungicides & Effects on Microorganism and Associated Process & References \\
\hline Apron, Arrest, and Captan & Reduces viable counts of Rhizobium ciceri & [69] \\
\hline Benomyl & Impacts mycorrhizal associations and nitrifying bacteria & [76] \\
\hline Benomyl, Mancozeb & Arrests activity of dehydrogenase, urease, and phosphatase enzymes & [77] \\
\hline Captan & $\begin{array}{l}\text { Inhibits aerobic N-fixing, nitrifying, denitrifying bacteria, nitrogenase } \\
\text { activity, phosphate solubilization and other fungi }\end{array}$ & [64] \\
\hline Captan and Thiram & $\begin{array}{c}\text { Decreases cell growth and nitrogenase activity in Azospirillum brasilense } \\
\text { even at a lower dose of } 10 \mathrm{mg} / \mathrm{L}\end{array}$ & [78] \\
\hline Captan and Carbendazim & Decreases nitrogenase enzyme activity & [36] \\
\hline Captan, Carboxin, Thiram & Inhibits the activity of bacteria responsible for denitrification & [79] \\
\hline Carbendazin and Thiram & Inhibits nodulation in legumes and thus $\mathrm{N}$-fixation process & [80] \\
\hline Chlorothalonil & Effects bacteria associated with nitrogen cycling & [76] \\
\hline Chlorothalonil, Azoxystro & Effects biocontrol agent(s) used against Fusarium wilt & [71] \\
\hline Copper fungicides & $\begin{array}{c}\text { Decreases population of bacteria, cellulolytic fungal species and } \\
\text { streptomycetes in sandy soil }\end{array}$ & [70] \\
\hline Dimethomorph & Inhibits nitrification and ammonification process in sandy soils & [81] \\
\hline Dinocap & Inhibits the activity of ammonifying bacteria & [82] \\
\hline Dithianon & Destrucs bacterial diversity in soil & [83] \\
\hline Fenpropimorph & Slows down bacterial activity in wetlands & [79] \\
\hline Fludioxonil & Toxic to algal activities & [84] \\
\hline Funaben, Baytan, Oxafun & Inhibits nitrogenase activity of methylotrophic bacteria at a higher dose & [85] \\
\hline Hexaconazole & Impacts bacteria involved in $\mathrm{N}$ cycling & [86] \\
\hline Mancozeb & Impacts on bacteria involved in N \& C cycle in soil & [82] \\
\hline $\begin{array}{l}\text { Mancozeb, Chlorothalonil, Metal } \\
\text { dithiocarbamates }\end{array}$ & Reduces nitrification process & [60] \\
\hline Metalaxyl & $\begin{array}{l}\text { Reduces urease activity continuously while phosphatase activity seems } \\
\text { stimulated but then reduces }\end{array}$ & [87] \\
\hline Metalaxyl & Disturbs activity of ammonifying and nitrifying bacteria & [19] \\
\hline Oxytetracycline & Acts as bactericide & [88] \\
\hline Pencycuron & Short-term impact on metabolically active soil bacteria & [89] \\
\hline Propiconazole & $\begin{array}{l}\begin{array}{c}\text { May retard plant growth-promoting effects of Azospirillum brasilense on } \\
\text { its host plant }\end{array}\end{array}$ & [90] \\
\hline Triadimefon & Deleterious to long-term soil bacterial community & [91] \\
\hline Triarimol and Captan & Reduces frequency of Aspergillus sp. & [92] \\
\hline
\end{tabular}

\subsection{Impact of Fungicides on Soil Enzymes and Biochemical Environments}

Several biochemical processes in soil are closely linked with enzymatic activities which are adversely affected by residues and toxic elements left after application of fungicides [93]. Fungicides benomyl, mancozeb, and tridemorph inhibit the soil enzymatic activity of dehydrogenase, urease, and phosphatase [77]. Activities of phosphomonoesterase and urease enzymes are also inhibited in soils treated with captan, trifloxystrobin, and thiram fungicides [94,95]. Yet, captan and thiram are classified as soil and seed protectant fungicides, respectively. However, the fungicide ridomil has a non-significant impact on the activity of a phosphatase enzyme [65]. These enzymes may be protected from degradation by adsorption on clays or humic substances in soil $[18,73]$. The smaller the size 
of the clay particle, the greater is the protection against the added fungicides [96]. The synthesis of amino acids of certain bacteria is repressed by some glucopyranosyl antibiotic fungicides $[93,97,98]$. The use of Cuin combination with mefenoxam can disturb soil microbial diversity as determined by structural and metabolic profiling. The population of ammonium oxidizing bacteria is decreased by the application of mefenoxam and mefenoxamp $\mathrm{Cu}$ fungicides after 60 days of application [65].

\section{Insecticides and Soil Microbial Environment}

\subsection{Impact of Insecticides on N-Fixing and Another Growth-Promoting Microorganism}

The applied insecticides affect the growth, survival, and working capacity of symbiotic rhizobial association with roots of legume plants resulting in dwindled atmospheric $\mathrm{N}$-fixation [80]. The antagonistic interaction between the applied insecticides and symbiotic $\mathrm{N}$-fixers differ with the specific chemical group of insecticide and the specific $\mathrm{N}$-fixer group. However, the field recommended doses of these chemicals had little effect on symbiotic $\mathrm{N}$-fixing bacteria [66]. The growth and population of Azotobacter are significantly inhibited because of phosphamidon, malathion, fenthion, methyl phosphorothioate, and parathion [99]. Nonetheless, insecticides like carbofuran, phorate, and disulfoton have little effect on the numbers of Azotobacter in the soil. Dinoseb, when used as an insecticide, inhibits the nitrogenase activity by $60 \%, 90 \%$ and $100 \%$ at 3 ppm, 6 ppm, 9 ppm, respectively [80]. While chlorpyrifos and their derivatives affect the biological activities of Pseudomonas fluorescences, Bacillus subtilis, Mycobacterium phlei, Trichoderma harzianum, Penicillium expansum, and Fusarium oxysporum [63]. Monocrotophos and cypermethrin have a negative impact on the population of soil bacteria, whereas fenvalerate has a slight effect [100]. Several other insecticides (i.e., chlorfluazuron, cypermethrin and phoxim) also has an inhibitory effect on soil microbes even at field recommended doses/concentrations [101]. The application of insecticides chlorpyrifos, imidacloprid, cypermethrin, endosulfan and carbofuran under field conditions causes considerable variation in soil bacterial populations [102]. Among the applied insecticides, chlorpyrifos has the most destructive effect on soil bacterial diversity. However, the insecticides monochrotophos, quinalphos, and cypermethrin show a positive effect at lower and antagonistic effects at higher doses [103]. Cypermethrin and monocrotophos are more harmful to soil bacteria and other microbes, whereas fenvalerate is less harmful [67].

\subsection{Influence of Insecticides on Soil Biochemistry}

The residues of insecticides, when applied at field-recommended rates, do not cause any harmful influence on the nitrification [80]. However, it is the prolonged use and the amounts of such insecticides that cause concerns. Nevertheless, at higher rates, it inhibits the process of nitrification and microbes involved in it [103]. For example, the biochemical process of nitrification and denitrification are reduced in soils contaminated with monocrotophos, lindane, dichlorvos, endosulfan, malathion, and chlorpyrifos when applied at concentrations of 0.02 to 10 times that of field recommended dose [104]. Insecticides have an adverse impact on soil microbes that are important to $\mathrm{N}$ transformation in soils, and the degree/extent of toxicity may vary based on the type and group of insecticide [105]. Further, the ammonification is less sensitive to insecticide residues. However, at higher doses, the ammonification process is often reduced [81]. Some insecticides have a neutral effect on ammonification (e.g., superacids ( 25 and $500 \mathrm{~g} / \mathrm{ha}$ ) and nuvacron (100 and $600 \mathrm{~g} / \mathrm{ha}$ ) did not affect the ammonification process but is significantly reduced at higher concentrations of $1000 \mathrm{~g} / \mathrm{ha}$ and $750 \mathrm{~g} / \mathrm{ha}$, respectively under controlled laboratory conditions [60].

\subsection{Impacts of Insecticides on Agrobiology}

There is a significant impact of pesticide contamination in soil ecosystem [106]. The repeated use of such complex chemicals (fertilizers, weedicides, insecticides, etc.) inevitably kill the microbial life that is invaluable for the healthy soil ecosystem [107]. Soil-dwelling microbes can be genetically modified using insecticides in a manner that is no longer helpful to the soil ecosystem and may 
eventually become resistant to the chemicals, intended to exterminate them. Insecticides have a higher effect on soil microbes compared to herbicides, albeit less than that of fungicides [12]. Some insecticides are detrimental to the growth and survival of beneficial microbes, but others may have stimulating or no effects [108]. For example, insecticides of the carbamate group (e.g., carbofuran, methiocarb, and carbaryl) have a wide range of negative impact on soil microbial environment [35] and enzymatic activity [109]. Similarly, insecticides belonging to the chemical group of organophosphates (i.e., dimethoate, diazinon, chlorpyrifos, quinalphos, and malathion) inhibit the growth and population of soil bacteria, fungi [99], and enzymes [110]. Arsenic, DDT, and lindane also have a negative effect on the microbial biomass [110], microbial processes, and enzymatic activities [68] that are attributable to their long-standing residual effect and persistence in soil. The effects of different insecticides on the soil micro-flora and fauna that are linked with nutrient cycling are presented in Table 3.

Table 3. Impact of insecticides on soil microorganisms, enzymes, and biochemical reactions.

\begin{tabular}{|c|c|c|}
\hline Insecticide & Effects on Microorganism and Associated Process & References \\
\hline $\begin{array}{l}\text { Amitraz, Aztec, Cyfluthrin, } \\
\text { Imidachlor, and Tebupirimphos }\end{array}$ & Reduces activities of urease and phosphatase enzymes for a week & [111] \\
\hline Arsenic, DDT, and Lindane & $\begin{array}{l}\text { Decreases microbial biomass and microbial and } \\
\text { enzymatic activities as a result of longer persistence in soil }\end{array}$ & [110] \\
\hline $\begin{array}{l}\text { Bensulfuron methyl and } \\
\text { Metsulfuron-methyl }\end{array}$ & Reduces soil microbial biomass & [112] \\
\hline Carbamate insecticides & Inhibits several soil microorganisms, enzymes and nitrogenase activity of Azospirillum & {$[35,99]$} \\
\hline Carbendazim, Imazetapir, Thiram & $\begin{array}{l}\text { Decreases nitrogenase activity in Rhizobium leguminosarum. R. trifolii, Bradyrhizobium sp. } \\
\text { and Sinorhizobium melilot in pot cultures as well as in field conditions }\end{array}$ & [80] \\
\hline $\begin{array}{l}\text { Carbofuran, Ethion, } \\
\text { and Hexaconazole }\end{array}$ & Inhibits nitrogenase activity of Anabaena doliolum by $38 \%$ within $48 \mathrm{~h}$ of application & [109] \\
\hline Chlorinated hydrocarbons & Inhibits methanogenesis & [61] \\
\hline $\begin{array}{l}\text { Chlorpyrifos, Dichlorvos, Phorate, } \\
\text { Monocrotophos, Methyl parathion, } \\
\text { Cypermethrin, Fenvalerate, } \\
\text { Methomyl and Quinalphos }\end{array}$ & $\begin{array}{l}\text { Increases phosphatase activity initially and later reduces gradually. } \\
\text { Phorate reduces the total bacterial population and N-fixing bacteria }\end{array}$ & [67] \\
\hline $\begin{array}{l}\text { Chlorpyrifos, Profenofos, } \\
\text { Pyrethrins, and Methylpyrimifos }\end{array}$ & $\begin{array}{l}\text { Reduces the population of aerobic N-fixing, nitrifying, } \\
\text { denitrifying bacteria and several fungi. Profenofos and Pyrethrins } \\
\text { decreases the activity of urease enzyme and nitrate reductase }\end{array}$ & [94] \\
\hline Chlorpyrifos, Quinalphos & Reduces ammonification process & [67] \\
\hline $\begin{array}{l}\text { Cyfluthrin, Fenpropimorph, } \\
\text { and Imidacloprid }\end{array}$ & Decreases nitrification and denitrification process, and stimulates sulphur oxidation & [111] \\
\hline Diazinon and Imidacloprid & Inhibits urease-producing bacterium (Proteus Vulgaris) & [113] \\
\hline $\begin{array}{l}\text { Lindane, Malathion, Diazinon, } \\
\text { and Imidacloprid }\end{array}$ & $\begin{array}{l}\text { Lindane inhibit state of nitrification, } \mathrm{N} \text {-availability, } \\
\text { P-solubilization and activity of phosphomonoesterase enzyme while the } \\
\text { opposite effect is observed in the case of Diazinon and Imidacloprid }\end{array}$ & [110] \\
\hline Metalaxyl and Mefenoxam & Decreases nitrogen-fixing bacteria and microbial biomass & [66] \\
\hline Methamidophos & Reduces microbial biomass by $41 \%-83 \%$ & [13] \\
\hline Neemix-4E & Reduces urease enzyme activity & [62] \\
\hline Organophosphate insecticide & $\begin{array}{l}\text { Impacts the activity of soil enzymes, several beneficial soil bacteria, } \\
\text { and fungal population and reduces N-mineralization rate }\end{array}$ & [99] \\
\hline Pentachlorophenol & Reduces nitrification & [114] \\
\hline Quinalphos & Reduces activity of enzyme phosphomonoesterase which recovers later & [115] \\
\hline Validamycin & Negatively effects phosphatase and urease enzyme which improves later & [116] \\
\hline
\end{tabular}

\section{Management Options}

Interestingly, since the advent of pesticides and its related derivatives, studies on their harmful effects have also been conducted for over a century, and many legislative actions and pesticide-related incidents have been documented [99]. The advent of fast and reliable analytical techniques has paved the way for greater understanding of the long-term effects of pesticides and related hazards posed to soil and natural ecosystems. Hence, with the ever-growing knowledge on pesticide-related health and environmental issues, new legislative actions are being amended or modified at a rapid pace suggesting major improvements in smarter and efficient pest control [117]. Integrated management of pesticides, its applications, and its residues have been proposed as an effective strategy for minimizing 
the harmful effects [118]. The biological control of pests has been at the forefront of many of the latest environmentally friendly approaches to tackling the menace of pesticide pollution. Some of the key effective management strategies are discussed below.

\subsection{Biopesticides}

Biopesticides are natural substances that can be derived from micro-organisms (microbial pesticides), plant-derived that contain added genetic material (plant-incorporated protectants-PIPs) and other naturally occurring products (biochemical pesticides) that offer pest control [119]. Biopesticides or biological pesticides play a significant part in pest management approaches for better and eco-friendly alternatives to chemical pesticides while minimizing pollution and contamination of soils and without compromising on soil microbial communities. Biopesticides ensure good soil health and environmental sustainability for eco-friendly agricultural production. Introducing beneficial microorganisms in any living system need to have a characteristic dominant role over disease-causing microbial populations. Mostly, these bio-products improve nutritional uptake efficiency of plants and increase crop performance, when applied directly to soils or as foliar applications. While biopesticides made from pathogenic microorganisms are specific to a target pest, biopesticides from beneficial interactors offer a better and ecologically solution. Furthermore, biopesticides do not harm the environment and soil microbes as compared to conventional chemical compounds [120].

The most commonly used biopesticides include Bacillus thuringiensis (Bt), Baculo viruses, Trichoderma, Azadirachta indica. PIPs, for example, Bacillus thuringiensis is the most globally popular, which is being used against moth larvae on plants, and the strains are made specifically for the larvae of mosquitoes and flies [121]. Important among microbial biopesticides are: (1) the Baculo viruses to target specific viruses which exterminates the disease-causing to lepidopterous insects of cotton, rice, and vegetables [122], (2) Trichoderma and Trichoderma-based products being effective against soil-borne diseases (i.e., root rot) and control of rots and wilts in dryland crops such as black gram (Vigna mungo), groundnut (Arachis hypogaea), chickpea (Cicer arietinum) and green gram (Vigna radiate) [120] and (3) the entomopathogenic nematodes (EPNs) of the genera Heterorhabditis sp. and the Steinernema sp. as potential agents against insect-pests of the genera Diptera, Coleoptera, Lepidoptera and Orthoptera and to kill many soil-dwelling insect-pests within 24-48 h [123]. The efficacy of EPN as a biopesticide is affected by nematode species, strain, production and storage conditions, and persistence in the habitat and susceptibility of target insect pests [123]. In comparison, several other bio-control agents take a few days or weeks to kill the target insect pest. EPNs are safe to most non-target beneficial soil organisms, and the ecosystem, easy to apply and are compatible with most agricultural chemical compounds. However, the cost of production, limited shelf-life and environmental conditions (moisture, temperature, UV sensitivity, etc.) are some of the major disadvantages in the broader application of EPNs [119].

\subsection{Plant-Based Products}

The active secretion of specific compounds from plant roots either stimulates or suppress the diverse soil microbial community [124]. For example, the secretion of strigolactones (a plant sesquiterpene) promotes symbiotic interactions by attracting mycorrhizal fungi of the order Glomeromycota [125]. The legumes release flavonoids which function as signaling molecules inviting $\mathrm{N}$-fixing bacteria in the rhizospheric zone for the establishment of rhizobial symbioses [126,127]. The plant growth-promoting rhizobacteria (PGPR) also benefits other soil microbes through the release of organic acids, for example, tomato roots release citric and fumaric acids which attract Pseudomonas fluorescence [128]. Neem cake oil is another good example of biopesticides as it offers the essential nutrition for soil microorganisms, and improves soil physicochemical properties besides controlling a wide range of pests [129]. Further, the usefulness of the botanical insecticide, azadirachtin (an allelochemical from neem) as an effective anti-fungal [130] and anti-microbial [131] compound has long been recognized. The effect of $10 \%$ azadirachtin granules (alcoholic extract of neem seed kernel mixed with china clay) on the microbial communities and their enzymatic activities suggested that azadirachtin at all doses exerts a suppressive effect [129]. 
Nonetheless, the negative impacts of neem (seed cake) are also reported. Elnasikh et al.(2011) [132] stated that neem seed cake impacts the population of Bactoderma, Nocardia, fungi, and the inorganic $\mathrm{N}$-users, including nitrifying bacteria negatively. However, neem cake impacts positively on the population of actinomycetes. The neem seed cake has the properties of inhibitors of nitrification and pesticide degradation [132]. In contrast, azadirachtin, neem extracts and their products (i.e., Neemix 4.5E and Eneem 3G) can impart low short-term toxicity on mycorrhizal Glomus intraradices [130]. Ipsilantis et al. (2012) [56] investigated the effect of bio-pesticides (pyrethrum, azadirachtin, terpens, and spinosad) along with synthetic fungicide carbendazim on exogenous AMF inoculum in pots and on indigenous AMF in field conditions. They reported that pyrethrum, terpenes, and spinosad did not significantly affect the structure and colonization ability of the AM fungi. However, the application of azadirachtin in pots caused selective inhibition of Glomus etunicatum strain and carbendazim completely hampered mycorrhizal colonization and the community structure of indigenous AMF [56]. This apparent disparity observed in neem, and various neem extract application may be attributed to the disturbance in the natural balance of some soil microbes and AMF. Several environmental, host, and symbiotic factors play a role in the observed trait variation among AMF $[133,134]$. The effect of neem oil cake can be similar to that of the azadirachtin in stimulating the population of Azotobacter [135]. Nitrosomonas, Nitrobacter, and Nitrosococcus are strongly affected by azadirachtin and any neem product or active ingredients present in neem seed, that is, medicines (epinimbin, Nimbin, salannin, nimin, nimbidin) at recommended as well as higher rates [130]. In general, the observed effects are pronounced at lower temperatures and low soil moisture levels [129]. The inhibitory influences of neem on nitrifying bacteria are also well documented by Kiran and Patra (2003) [135]. The application of neem seed kernel extract inhibits nitrification during 7 to 21 days of application, and this inhibition is more in acid soils and less in sodic and normal soils. The same trend is observed in activities of urease enzyme [136]. However, the activity of urease enzyme is affected temporarily by Neemix- a $4 \mathrm{E}$ application which ranges from being neither severe nor extended enough to be considered harmful to the soil microbes [62]. Similarly, azadirachtin granules do not affect the soil dehydrogenase activity in any way even at higher doses, while the activities of phosphatase and dehydrogenase enzymes are considerably improved with the application of botanical pesticide at the recommended dose [137]. The increase in phosphatase enzyme activity is attributed to the effect of azadirachtin on the soil microorganisms, subsequent decomposition and release of the phosphates from the dead microbial biomass [129].

\subsection{Microbial-Based-Products}

Microbial inoculation for plant growth and soil health promotion has been at the forefront of many new and exciting innovations in sustainable crop production endeavors [59]. Correspondingly, seed and soil inoculations of beneficial microorganisms have gained tremendous interest in recent years with the advent of a group of bacteria called the plant growth-promoting bacteria (PGPR) [138] harboring several polyfunctional abilities. Microbial biopesticides, not only enhance soil fertility but are also environmentally friendly and safe for crops. The percentage of soil MBC is significantly enhanced overtime in biopesticide treated soils (like Folicon, Bacillus subtilis, Pseudomonas florescent, Paeciliomyces lilacinus and Beauveria bassiana) compared with that under control. The maximum increment $(1.46 \%)$ is noticed with Paeciliomyces lilacinus, and the lowest $(0.98 \%)$ with Bacillus subtilis treated soils over a period of 2 to 6 weeks of treatment [139]. Similarly, seed dressing with Pseudomonas at $3 \mathrm{~g} / \mathrm{kg}$ results in increase in number of fungal $\left(12.27 \times 10^{4} \mathrm{CFU}\right.$ per $\mathrm{g}$ soil $)$, actinomycetes $\left(11.4 \times 10^{5} \mathrm{CFU}\right.$ per g soil) and Bradyrhizobium japonicum population (27.7 to $35.2 \times 10^{4} \mathrm{CFU}$ per g soil) over that in control at the time of harvest of oilseeds [140]. Genetically engineered plants have considerable effects on non-target soil microorganisms, soil enzymes and root colonization of G. mosseae [137]. While some reports indicate that $B t$ cotton may have positive effects on soil-flora and fauna, others have reported negative effects [141]. The effects caused by transgenic plants on soil microbes are temporary and occur at a particular stage of crop growth [142]. The transgene proteins in transgenic plants produce the chemical substances that are potentially lethal to beneficial soil micro-fauna and flora, including 
mycorrhizal fungi that are involved in soil organic matter [143]. For example, the crystal toxin protein produced by leaves, stems, and roots of transgenic plants expressing the gene of $\mathrm{Bt}$ is one of the most common transgene proteins that release large quantities of toxins into the soil ecosystem. It enters the soil through biomass incorporation, death, and turnover of sloughed root cells and root exudates [143]. However, measurements of Bt corn uptake and insecticide use in the US indicate that the overall pesticide use dropped $0.6 \%$ per year between 1980 and 2007. It is yet to be investigated further whether an increase in pesticide use is warranted underdevelopment of some resistant insects [144].

\subsection{Transgenic Herbicide-Resistant Crops}

The root exudates of the genetically modified herbicide-resistant crops in the soil environment interact either positively or negatively with living organisms that inhabit in soil [142]. The genetically transformed glyphosate-resistant rapeseed containing the 'pat' gene (Brassica napus) influences soil microorganisms such as Bacillus, Micrococcus, Variovarax, Flavobacterium, and Pseudomonas [137]. The populations of these microbes are scarcely observed on the root surface of transgenic rapeseed cultivars compared to that of non-transgenic cultivars. The group of root-endophytic bacteria of the transgenic cultivar has lesser diversity than that of non-transgenic cultivar [145]. In contrast, the transgenic cultivars of maize and sugar beet containing the same pat gene have a non-significant influence on the diversity of rhizospheric bacteria [146]. Interestingly, glyphosate-resistant oilseed rape has considerable effects on the communities of soil biota, whereas glufosinate resistant oilseed rape, sugar beet, and maize show non-significant effects. This trend is present may be due to the different chemical makeup of herbicides and soil types that causes varied effects on microbial populations or due to the different root exudates altered by the insertion of different transgenes in transgenic plants [143]. Powell et al. (2007) [44] evaluated nine soybean cultivars (six were genetically modified) to express transgenic cp4-epsps, in the presence of AMF and Bradyrhizobium japonicum and reported differences in nodule numbers, biomass and mycorrhizal colonization among cultivars.

\section{Conclusions}

The mandate for agriculture development is to feed and provide adequate nutrition and surplus to the mounting human population without compromising on ecology and environment of the biosphere. Pesticides and their use are considered as magic bullets in developing nations. Pesticides cause serious hazards to soil environment and human health because a lot of pesticides and their derivatives remain in the soil system for a considerable period. Most pesticides negatively affect the biological functionaries of microbes, their diversity, composition, and biochemical processes. Pesticides cause imbalance of soil fertility which directly affects crop yield.

Judicious and discriminate use of pesticides is critical because most harmful effects are caused by the application doses that exceed the recommended rates. The education of farmers, distributors, industry, policymakers, and other stakeholders in the discriminate use of pesticide is critical to reducing the adverse effects on humans and the environment. Well-designed experiments are needed on the long-term effect of pesticides on microbial communities and their long-term eco-toxicological effects in the soil environment.

Author Contributions: Conceptualization, R.S.M., S.K. and V.V.; methodology, M.K.J., G.S.Y. and M.P.S.; formal analysis, M.B., T.D. and V.P.; resources, M.B., C.K.J.; data curation, T.D.M.; writing-original draft preparation, R.S.M. and S.K.; writing-review and editing, R.D. and S.I.P.; supervision, R.L.; All authors have read and agreed to the published version of the manuscript.

Funding: This research received no external funding.

Acknowledgments: The work was supported by the project of Technology Agency of the Czech Republic TH03030319: "Promoting the functional diversity of soil organisms by applying classical and modified stable organic matter while preserving the soil's production properties".

Conflicts of Interest: The authors declare no conflict of interest. 


\section{References}

1. Yáñ ez, L.; Ortiz, D.; Calderón, J.; Batres, L.; Carrizales, L.; Mejía, J.; Martínez, L.; García-Nieto, E.; Díaz-Barriga, F. Overview of human health and chemical mixtures: Problems facing developing countries. Environ. Health Perspect. 2002, 110, 901-909. [CrossRef]

2. Mishra, P.K.; Giagli, K.; Tsalagkas, D.; Mishra, H.; Talegaonkar, S.; Gryc, V.; Wimmer, R. Changing Face of Wood Science in Modern Era: Contribution of Nanotechnology. Recent Pat. Nanotechnol. 2018, 12, $13-21$. [CrossRef]

3. Mishra, P.K.; Gregor, T.; Wimmer, R. Utilising Brewer's Spent Grain as a Source of Cellulose Nanofibres Following Separation of Protein-based Biomass. BioResources 2017, 12, 107-116. [CrossRef]

4. Marfo, T.D.; Datta, R.; Pathan, S.I.; Vranová, V. Ecotone Dynamics and Stability from Soil Scientific Point of View. Diversity 2019, 11, 53. [CrossRef]

5. Danso Marfo, T.; Datta, R.; Vranová, V.; Ekielski, A. Ecotone Dynamics and Stability from Soil Perspective: Forest-Agriculture Land Transition. Agriculture 2019, 9, 228. [CrossRef]

6. Meena, H.; Meena, R.S.; Rajput, B.S.; Kumar, S. Response of bio-regulators to morphology and yield of clusterbean [Cyamopsis tetragonoloba (L.) Taub.] under different sowing environments. J. Appl. Nat. Sci. 2016, 8, 715-718. [CrossRef]

7. Food and Agriculture Organization of the United Nations. FAOSTAT Statistical Database; FAO: Rome, Italy, 2019.

8. Önder, M.; Ceyhan, E.; Kahraman, A. Effects of Agricultural Practices on Environment. Biol. Environ. Chem. 2011, 24, 28-32.

9. Oliveira, C.M.; Auad, A.M.; Mendes, S.M.; Frizzas, M.R. Crop losses and the economic impact of insect pests on Brazilian agriculture. Crop Prot. 2014, 56, 50-54. [CrossRef]

10. Meena, R.S.; Bohra, J.S.; Singh, S.P.; Meena, V.S.; Verma, J.P.; Verma, S.K.; Sihag, S.K. Towards the prime response of manure to enhance nutrient use efficiency and soil sustainability a current need: A book review. J. Clean. Prod. 2016, 112, 1258-1260. [CrossRef]

11. Bahadur, S.; Verma, S.K.; Prasad, S.K.; Madane, A.J.; Maurya, S.P.; Gaurav Verma, V.K.; Sihag, S.K. Eco-friendly weed management for sustainable crop production-A review. J. Crop Weed 2015, 11, 181-189.

12. Aktar, W.; Sengupta, D.; Chowdhury, A. Impact of pesticides use in agriculture: Their benefits and hazards. Interdiscip. Toxicol. 2009, 2, 1-12. [CrossRef] [PubMed]

13. Wang, M.-C.; Gong, M.; Zang, H.-B.; Hua, X.-M.; Yao, J.; Pang, Y.-J.; Yang, Y.-H. Effect of Methamidophos and Urea Application on Microbial Communities in Soils as Determined by Microbial Biomass and Community Level Physiological Profiles. J. Environ. Sci. Health B 2006, 41, 399-413. [CrossRef] [PubMed]

14. Miller, G.T. Sustaining the Earth; Brooks/Cole: Monterey County, CA, USA, 2004; ISBN 9780534400880.

15. Lo, C.-C. Effect of pesticides on soil microbial community. J. Environ. Sci. Health Part B 2010, 45, 348-359. [CrossRef]

16. Santos, A.; Flores, M. Effects of glyphosate on nitrogen fixation of free-living heterotrophic bacteria. Lett. Appl. Microbiol. 1995, 20, 349-352. [CrossRef]

17. Fabra, A.; Duffard, R.; Duffard, A.E. de Toxicity of 2,4-Dichlorophenoxyacetic Acid to Rhizobium sp in Pure Culture. Bull. Environ. Contam. Toxicol. 1997, 59, 645-652. [CrossRef] [PubMed]

18. Hussain, S.; Siddique, T.; Saleem, M.; Arshad, M.; Khalid, A. Chapter 5 Impact of Pesticides on Soil Microbial Diversity, Enzymes, and Biochemical Reactions. Adv. Agron. 2009, 102, 159-200.

19. Monkiedje, A.; Spiteller, M. Degradation of Metalaxyl and Mefenoxam and Effects on the Microbiological Properties of Tropical and Temperate Soils. Int. J. Environ. Res. Public. Health 2005, 2, 272-285. [CrossRef]

20. Bano, S.A.; Iqbal, S.M. Biological Nitrogen Fixation to Improve Plant Growth and Productivity. Int. J. Agric. Innov. Res. 2016, 4, 2319-1473.

21. Reitz, M.U.; Gifford, M.L.; Schäfer, P. Hormone activities and the cell cycle machinery in immunity-triggered growth inhibition. J. Exp. Bot. 2015, 66, 2187-2197. [CrossRef]

22. Milosevic, N.; Govedarica, M. Effect of herbicides on microbiological properties of soil. Matica Srp. Proc. Nat. Sci. 2002, 102, 5-21. [CrossRef]

23. Kremer, R.J.; Means, N.E. Glyphosate and glyphosate-resistant crop interactions with rhizosphere microorganisms. Eur. J. Agron. 2009, 31, 153-161. [CrossRef] 
24. Yadav, G.; Datta, R.; Imran Pathan, S.; Lal, R.; Meena, R.; Babu, S.; Das, A.; Bhowmik, S.; Datta, M.; Saha, P. Effects of Conservation Tillage and Nutrient Management Practices on Soil Fertility and Productivity of Rice (Oryza sativa L.)-Rice System in North Eastern Region of India. Sustainability 2017, 9, 1816. [CrossRef]

25. Santos, J.B.; Jakelaitis, A.; Silva, A.A.; Costa, M.D.; Manabe, A.; Silva, M.C.S. Action of two herbicides on the microbial activity of soil cultivated with common bean (Phaseolus vulgaris) in conventional-till and no-till systems. Weed Res. 2006, 46, 284-289. [CrossRef]

26. Chen, F.; Dixon, R.A. Lignin modification improves fermentable sugar yields for biofuel production. Nat. Biotechnol. 2007, 25, 759-761. [CrossRef]

27. Datta, R.; Kelkar, A.; Baraniya, D.; Molaei, A.; Moulick, A.; Meena, R.S.; Formanek, P. Enzymatic degradation of lignin in soil: A review. Sustainability 2017, 9, 1163. [CrossRef]

28. Mishra, P.K.; Wimmer, R. Aerosol assisted self-assembly as a route to synthesize solid and hollow spherical lignin colloids and its utilization in layer by layer deposition. Ultrason. Sonochem. 2017, 35, 45-50. [CrossRef]

29. Mishra, P.K.; Ekielski, A. The Self-Assembly of Lignin and Its Application in Nanoparticle Synthesis: A Short Review. Nanomaterials 2019, 9, 243. [CrossRef]

30. Smith, A.R.W.; Beadle, C.A. Induction of enzymes of 2,4-dichlorophenoxyacetate degradation in Burkholderia cepacia 2a and toxicity of metabolic intermediates. Biodegradation 2008, 19, 669-681. [CrossRef]

31. Tsui, M.T.K.; Chu, L.M. Aquatic toxicity of glyphosate-based formulations: Comparison between different organisms and the effects of environmental factors. Chemosphere 2003, 52, 1189-1197. [CrossRef]

32. Brtnicky, M.; Dokulilova, T.; Holatko, J.; Pecina, V.; Kintl, A.; Latal, O.; Vyhnanek, T.; Prichystalova, J.; Datta, R. Long-Term Effects of Biochar-Based Organic Amendments on Soil Microbial Parameters. Agronomy 2019, 9, 747. [CrossRef]

33. Khan, M.S.; Zaidi, A.; Rizvi, P.Q. Biotoxic Effects of Herbicides on Growth, Nodulation, Nitrogenase Activity, and Seed Production in Chickpeas. Commun. Soil Sci. Plant Anal. 2006, 37, 1783-1793. [CrossRef]

34. Seghers, D.; Verthé, K.; Reheul, D.; Bulcke, R.; Siciliano, S.D.; Verstraete, W.; Top, E.M. Effect of long-term herbicide applications on the bacterial community structure and function in an agricultural soil. FEMS Microbiol. Ecol. 2003, 46, 139-146. [CrossRef]

35. Sannino, F.; Gianfreda, L. Pesticide influence on soil enzymatic activities. Chemosphere 2001, 45, 417-425. [CrossRef]

36. Chalam, A.V.; Sasikala, C.; Ramana, C.V.; Uma, N.R.; Rao, P.R. Effect of Pesticides on the Diazotrophic Growth and Nitrogenase Activity of Purple Nonsulfur Bacteria. Bull. Environ. Contam. Toxicol. 1997, 58, 463-468. [CrossRef]

37. Fox, J.E.; Starcevic, M.; Kow, K.Y.; Burow, M.E.; McLachlan, J.A. Nitrogen fixation: Endocrine disrupters and flavonoid signalling. Nature 2001, 413, 128-129. [CrossRef]

38. Syamsul Arif, M.A.; Houwen, F.; Verstraete, W. Agricultural factors affecting methane oxidation in arable soil. Biol. Fertil. Soils 1996, 21, 95-102. [CrossRef]

39. Subhani, A.; El-ghamry, A.M.; Changyong, H.; Jianming, X. Effects of Pesticides (Herbicides) on Soil Microbial Biomass - A Review. Pak. J. Biol. Sci. 2000, 3, 705-709.

40. Singh, G.; Wright, D. In vitro studies on the effects of herbicides on the growth of rhizobia. Lett. Appl. Microbiol. 2002, 35, 12-16. [CrossRef]

41. Nowak, J.; Kaklewski, K.; Klódka, D. Influence of various concentrations of selenic acid (IV) on the activity of soil enzymes. Sci. Total Environ. 2002, 291, 105-110. [CrossRef]

42. Makarian, H.; Poozesh, V.; Asghari, H.R.; Nazari, M. Interaction Effects of Arbuscular Mycorrhiza Fungi and Soil Applied Herbicides on Plant Growth. Commun. Soil Sci. Plant Anal. 2016, 47, 619-629. [CrossRef]

43. Meena, R.S.; Meena, V.S.; Meena, S.K.; Verma, J.P. The needs of healthy soils for a healthy world. J. Clean. Prod. 2015, 102, 560-561. [CrossRef]

44. Powell, J.R.; Gulden, R.H.; Hart, M.M.; Campbell, R.G.; Levy-Booth, D.J.; Dunfield, K.E.; Pauls, K.P.; Swanton, C.J.; Trevors, J.T.; Klironomos, J.N. Mycorrhizal and Rhizobial Colonization of Genetically Modified and Conventional Soybeans. Appl. Environ. Microbiol. 2007, 73, 4365-4367. [CrossRef] [PubMed]

45. Zawoznik, M.S.; Tomaro, M.L. Effect of chlorimuron-ethyl onBradyrhizobium japonicum and its symbiosis with soybean. Pest Manag. Sci. 2005, 61, 1003-1008. [CrossRef] [PubMed]

46. dos Santos, J.B.; Ferreira, E.A.; Kasuya, M.C.M.; da Silva, A.A.; de Oliveira Procópio, S. Tolerance of Bradyrhizobium strains to glyphosate formulations. Crop Prot. 2005, 24, 543-547. [CrossRef] 
47. Strandberg, M.; Scott-Fordsmand, J.J. Effects of pendimethalin at lower trophic levels-A review. Ecotoxicol. Environ. Saf. 2004, 57, 190-201. [CrossRef]

48. Govedarica, M.; Miloševiã, N.; Konstantinoviã, B. Uticaj dimetenamida i metalahlora na mikrobiološka svojstva zemljišta pod šeãernom repom. V Jugosl. Savetov. O Zašt. Bilja Zlatibor 2001, 12, 3-8.

49. Smith, S.E.; Read, D. Growth and carbon economy of arbuscular mycorrhizal symbionts. Mycorrhizal Symbiosis 2008, 117-144. [CrossRef]

50. Pasaribu, A.; Mohamad, R.B.; Hashim, A.; Rahman, Z.A.; Omar, D.; Morshed, M.M.; Selangor, D.E. Effect of herbicide on sporulation and infectivity of vesicular arbuscular mycorrhizal (Glomus mosseae) symbiosis with peanut plant. J. Anim. Plant Sci. 2013, 23, 1671-1678.

51. Das, A.C.; Debnath, A.; Mukherjee, D. Effect of the herbicides oxadiazon and oxyfluorfen on phosphates solubilizing microorganisms and their persistence in rice fields. Chemosphere 2003, 53, 217-221. [CrossRef]

52. Zaller, J.G.; Heigl, F.; Ruess, L.; Grabmaier, A. Glyphosate herbicide affects belowground interactions between earthworms and symbiotic mycorrhizal fungi in a model ecosystem. Sci. Rep. 2014, 4, 5634. [CrossRef]

53. Savin, M.C.; Purcell, L.C.; Daigh, A.; Manfredini, A. Response of Mycorrhizal Infection to Glyphosate Applications and P Fertilization in Glyphosate-Tolerant Soybean, Maize, and Cotton. J. Plant Nutr. 2009, 32, 1702-1717. [CrossRef]

54. Sharma, M.P.; Buyer, J.S. Comparison of biochemical and microscopic methods for quantification of arbuscular mycorrhizal fungi in soil and roots. Appl. Soil Ecol. 2015, 95, 86-89. [CrossRef]

55. Druille, M.; Omacini, M.; Golluscio, R.A.; Cabello, M.N. Arbuscular mycorrhizal fungi are directly and indirectly affected by glyphosate application. Appl. Soil Ecol. 2013, 72, 143-149. [CrossRef]

56. Ipsilantis, I.; Samourelis, C.; Karpouzas, D.G. The impact of biological pesticides on arbuscular mycorrhizal fungi. Soil Biol. Biochem. 2012, 45, 147-155. [CrossRef]

57. Gupta, A.; Aggarwal, A.; Chhavi, M.; Kumar, A.; Tanwar, A. Effect of herbicides Fenoxaprop-P-ethyl and 2, 4-D Ethyl-ester on soil mycoflora including VAM fungi in wheat crop. Indian J. Weed Sci. India 2011, 43, 32-40.

58. Kiers, E.T.; Duhamel, M.; Beesetty, Y.; Mensah, J.A.; Franken, O.; Verbruggen, E.; Fellbaum, C.R.; Kowalchuk, G.A.; Hart, M.M.; Bago, A. Reciprocal rewards stabilize cooperation in the mycorrhizal symbiosis. Science 2011, 333, 880-882. [CrossRef] [PubMed]

59. Timmusk, S.; Behers, L.; Muthoni, J.; Muraya, A.; Aronsson, A.-C. Perspectives and challenges of microbial application for crop improvement. Front. Plant Sci. 2017, 8, 49. [CrossRef]

60. Kinney, C.A.; Mandernack, K.W.; Mosier, A.R. Laboratory investigations into the effects of the pesticides mancozeb, chlorothalonil, and prosulfuron on nitrous oxide and nitric oxide production in fertilized soil. Soil Biol. Biochem. 2005, 37, 837-850. [CrossRef]

61. Mahía, J.; Cabaneiro, A.; Carballas, T.; Díaz-Raviña, M. Microbial biomass and C mineralization in agricultural soils as affected by atrazine addition. Biol. Fertil. Soils 2008, 45, 99-105. [CrossRef]

62. Antonious, G.F. Impact of Soil Management and Two Botanical Insecticides on Urease and Invertase Activity. J. Environ. Sci. Health Part B 2003, 38, 479-488. [CrossRef]

63. Virág, D.; Naár, Z.; Kiss, A. Microbial Toxicity of Pesticide Derivatives Produced with UV-photodegradation. Bull. Environ. Contam. Toxicol. 2007, 79, 356-359. [CrossRef] [PubMed]

64. Sáez, F.; Pozo, C.; Gómez, M.A.; Martínez-Toledo, M.V.; Rodelas, B.; Gónzalez-López, J. Growth and denitrifying activity of Xanthobacter autotrophicus CECT 7064 in the presence of selected pesticides. Appl. Microbiol. Biotechnol. 2005, 71, 563-567. [CrossRef] [PubMed]

65. Demanou, J.; Sharma, S.; Weber, A.; Wilke, B.-M.; Njine, T.; Monkiedje, A.; Munch, J.C.; Schloter, M. Shifts in microbial community functions and nitrifying communities as a result of combined application of copper and mefenoxam. FEMS Microbiol. Lett. 2006, 260, 55-62. [CrossRef] [PubMed]

66. Monkiedje, A. Soil quality changes resulting from the application of the fungicides mefenoxam and metalaxyl to a sandy loam soil. Soil Biol. Biochem. 2002, 34, 1939-1948. [CrossRef]

67. Madhuri, R.J.; Rangaswamy, V. Influence of selected insecticides on phosphatase activity in groundnut (Arachis hypogeae L.) soils. J. Environ. Biol. 2002, 23, 393-397. [PubMed]

68. Van Zwieten, L.; Ayres, M.R.; Morris, S.G. Influence of arsenic co-contamination on DDT breakdown and microbial activity. Environ. Pollut. 2003, 124, 331-339. [CrossRef]

69. Kyei-Boahen, S.; Slinkard, A.E.; Walley, F.L. Rhizobial survival and nodulation of chickpea as influenced by fungicide seed treatment. Can. J. Microbiol. 2001, 47, 585-589. [CrossRef] 
70. Kostov, O.; Van Cleemput, O. Microbial Activity of Cu Contaminated Soils and Effect of Lime and Compost on Soil Resiliency. Compost Sci. Util. 2001, 9, 336-351. [CrossRef]

71. Fravel, D.R.; Deahl, K.L.; Stommel, J.R. Compatibility of the biocontrol fungus Fusarium oxysporum strain CS-20 with selected fungicides. Biol. Control 2005, 34, 165-169. [CrossRef]

72. Cycoń, M.; Piotrowska-Seget, Z.; Kaczyńska, A.; Kozdrój, J. Microbiological characteristics of a sandy loam soil exposed to tebuconazole and $\lambda$-cyhalothrin under laboratory conditions. Ecotoxicology 2006, 15, 639-646. [CrossRef]

73. Datta, R.; Anand, S.; Moulick, A.; Baraniya, D.; Pathan, S.I.; Rejsek, K.; Vranova, V.; Sharma, M.; Sharma, D.; Kelkar, A.; et al. How enzymes are adsorbed on soil solid phase and factors limiting its activity: A Review. Int. Agrophysics 2017, 31, 287-302. [CrossRef]

74. Smith, M.D.; Hartnett, D.C.; Rice, C.W. Effects of long-term fungicide applications on microbial properties in tallgrass prairie soil. Soil Biol. Biochem. 2000, 32, 935-946. [CrossRef]

75. Murillo-Williams, A.; Pedersen, P. Arbuscular Mycorrhizal Colonization Response to Three Seed-Applied Fungicides. Agron. J. 2008, 100, 795. [CrossRef]

76. Chen, S.-K.; Edwards, C.A.; Subler, S. Effects of the fungicides benomyl, captan and chlorothalonil on soil microbial activity and nitrogen dynamics in laboratory incubations. Soil Biol. Biochem. 2001, 33, 1971-1980. [CrossRef]

77. Shukla, A.K. Impact of fungicides on soil microbial population and enzyme activities. Acta Bot. Indica 2000, 28, 85-88.

78. Di Ciocco, C.A.; Rodríguez, C.E. Effect of the fungicide captan on Azospirillum brasilense Cd in pure culture and associated with Setaria italica. Rev. Argent. Microbiol. 1997, 29, 152.

79. Milenkovski, S.; Bååth, E.; Lindgren, P.E.; Berglund, O. Toxicity of fungicides to natural bacterial communities in wetland water and sediment measured using leucine incorporation and potential denitrification. Ecotoxicology 2010, 19, 285-294. [CrossRef]

80. Niewiadomska, A. Effect of Carbendazim, Imazetapir and Thiram on Nitrogenase Activity, the Number of Microorganisms in Soil and Yield of Red Clover (Trifolium pratense L.). Pol. J. Environ. Stud. 2004, 13, 4.

81. Cycoń, M.; Piotrowska-Seget, Z.; Kozdrój, J. Responses of indigenous microorganisms to a fungicidal mixture of mancozeb and dimethomorph added to sandy soils. Int. Biodeterior. Biodegrad. 2010, 64, 316-323. [CrossRef]

82. Černohlávková, J.; Jarkovský, J.; Hofman, J. Effects of fungicides mancozeb and dinocap on carbon and nitrogen mineralization in soils. Ecotoxicol. Environ. Saf. 2009, 72, 80-85. [CrossRef]

83. Liebich, J.; Schäffer, A.; Burauel, P. Structural and functional approach to studying pesticide side-effects on specific soil functions. Environ. Toxicol. Chem. 2003, 22, 784-790. [CrossRef] [PubMed]

84. Verdisson, S.; Couderchet, M.; Vernet, G. Effects of procymidone, fludioxonil and pyrimethanil on two non-target aquatic plants. Chemosphere 2001, 44, 467-474. [CrossRef]

85. Durska, G. Fungicide effect on nitrogenase activity in methylotrophic bacteria. Pol. J. Microbiol. 2004, 53, 155-158.

86. Madhuri, R.J.; Rangaswamy, V. Influence of selected fungicides on microbial population in groundnut (Arachis hypogeae L.) soils. Pollut. Res. 2003, 22, 205-212.

87. Sukul, P. Enzymatic activities and microbial biomass in soil as influenced by metalaxyl residues. Soil Biol. Biochem. 2006, 38, 320-326. [CrossRef]

88. Yang, Q.; Zhang, J.; Zhu, K.; Zhang, H. Influence of oxytetracycline on the structure and activity of microbial community in wheat rhizosphere soil. J. Environ. Sci. 2009, 21, 954-959. [CrossRef]

89. Pal, R.; Chakrabarti, K.; Chakraborty, A.; Chowdhury, A. Pencycuron application to soils: Degradation and effect on microbiological parameters. Chemosphere 2005, 60, 1513-1522. [CrossRef]

90. Pereyra, M.A.; Ballesteros, F.M.; Creus, C.M.; Sueldo, R.J.; Barassi, C.A. Seedlings growth promotion by Azospirillum brasilense under normal and drought conditions remains unaltered in Tebuconazole-treated wheat seeds. Eur. J. Soil Biol. 2009, 45, 20-27. [CrossRef]

91. Yen, J.-H.; Chang, J.-S.; Huang, P.-J.; Wang, Y.-S. Effects of fungicides triadimefon and propiconazole on soil bacterial communities. J. Environ. Sci. Health Part B 2009, 44, 681-689. [CrossRef]

92. Wainwright, M.; Pugh, G.J.F. Effect of fungicides on the numbers of micro-organisms and frequency of cellulolytic fungi in soils. Plant Soil 1975, 43, 561-572. [CrossRef] 
93. Carr, J.F.; Gregory, S.T.; Dahlberg, A.E. Severity of the Streptomycin Resistance and Streptomycin Dependence Phenotypes of Ribosomal Protein S12 of Thermus thermophilus Depends on the Identity of Highly Conserved Amino Acid Residues. J. Bacteriol. 2005, 187, 3548-3550. [CrossRef] [PubMed]

94. Martínez-Toledo, M.V.; Salmerón, V.; Rodelas, B.; Pozo, C.; González-López, J. Effects of the fungicide Captan on some functional groups of soil microflora. Appl. Soil Ecol. 1998, 7, 245-255. [CrossRef]

95. Marfo, T.D.; Datta, R.; Lojkova, L.; Janous, D.; Pavelka, M.; Formanek, P. Limitation of Activity of Acid Phosphomonoesterase in Soils; Springer: Wien, Austria, 2015; Volume 47, p. 1691.

96. Datta, R.; Vranová, V.; Pavelka, M.; Rejšek, K.; Formánek, P. Effect of soil sieving on respiration induced by low-molecular-weight substrates. Int. Agrophysics 2014, 28, 119-124. [CrossRef]

97. Molaei, A.; Lakzian, A.; Datta, R.; Haghnia, G.; Astaraei, A.; Rasouli-Sadaghiani, M.; Ceccherini, M.T. Impact of chlortetracycline and sulfapyridine antibiotics on soil enzyme activities. Int. Agrophys. 2017, 31, 499-505. [CrossRef]

98. Molaei, A.; Lakzian, A.; Haghnia, G.; Astaraei, A.; Rasouli-Sadaghiani, M.; Ceccherini, M.T.; Datta, R. Assessment of some cultural experimental methods to study the effects of antibiotics on microbial activities in a soil: An incubation study. PLoS ONE 2017, 12, e0180663. [CrossRef]

99. Pandey, S.; Singh, D.K. Total bacterial and fungal population after chlorpyrifos and quinalphos treatments in groundnut (Arachis hypogaea L.) soil. Chemosphere 2004, 55, 197-205. [CrossRef]

100. Survery, S.; Ahmad, S.; Subhan, S.A.; Ajaz, M.; Rasool, S.A. Hydrocarbon Degrading Bacteria from Pakistani Soil: Isolation, Identification, Screening and Genetical Studies. Pak. J. Biol. Sci. 2004, 7, 1518-1522.

101. Amirkhanov, D.V.; Nikolenko, A.G.; Bagautdinov, F.Y.; Kirillova, S.S. Effect of production dosage of gamma-HCCH, foxim, cypermethrin and chlorfluazuron on soil microorganisms [grey forest soils].[Russian]. Agrokhimiya 1994, 2, 83-88.

102. Ahmed, S.; Ahmad, M. Note: Toxicity of some insecticides onBracon hebetor under laboratory conditions. Phytoparasitica 2006, 34, 401-404. [CrossRef]

103. Gundi, V.A.K.B.; Narasimha, G.; Reddy, B.R. Interaction Effects of Insecticides on Microbial Populations and Dehydrogenase Activity in a Black Clay Soil. J. Environ. Sci. Health Part B 2005, 40, 69-283. [CrossRef]

104. Madhaiyan, M.; Poonguzhali, S.; Hari, K.; Saravanan, V.S.; Sa, T. Influence of pesticides on the growth rate and plant-growth promoting traits of Gluconacetobacter diazotrophicus. Pestic. Biochem. Physiol. 2006, 84, 143-154. [CrossRef]

105. Das, A.C.; Mukherjee, D. Influence of Insecticides on Microbial Transformation of Nitrogen and Phosphorus in Typic Orchragualf Soil. J. Agric. Food Chem. 2000, 48, 3728-3732. [CrossRef]

106. Zhu, G.; Wu, H.; Guo, J.; Kimaro, F.M.E. Microbial Degradation of Fipronil in Clay Loam Soil. Water. Air. Soil Pollut. 2004, 153, 35-44. [CrossRef]

107. Shang, Y.; Hasan, M.; Ahammed, G.J.; Li, M.; Yin, H.; Zhou, J. Applications of nanotechnology in plant growth and crop protection: A review. Molecules 2019, 24, 2558. [CrossRef]

108. Patnaik, G.K.; Kanungo, P.K.; Adhya, T.K.; Rajaramamohan Rao, V. Effect of repeated applications of gamma-hexachlorocyclohexane $(\gamma-\mathrm{HCH})$ on nitrogenase activity and nitrogen-fixing bacteria associated with rhizosphere of tropical rice. Microbiol. Res. 1996, 151, 375-378. [CrossRef]

109. Kalam, A.; Mukherjee, A.K. Influence of hexaconazole, carbofuran and ethion on soil microflora and dehydrogenase activities in soil and intact cell. Indian J. Exp. Biol. (IJEB) 2001, 39, 90-94.

110. Singh, J.; Singh, D.K. Dehydrogenase and phosphomonoesterase activities in groundnut (Arachis hypogaea L.) field after diazinon, imidacloprid and lindane treatments. Chemosphere 2005, 60, 32-42. [CrossRef]

111. Tu, C.M. Effect of five insecticides on microbial and enzymatic activities in sandy soil. J. Environ. Sci. Health Part B 1995, 30, 289-306. [CrossRef]

112. El-Ghamry, A.M.; Xu, J.M.; Huang, C.Y.; Gan, J. Microbial response to bensulfuron-methyl treatment in soil. J. Agric. Food Chem. 2002, 50, 136-139. [CrossRef]

113. Ingram, C.W.; Coyne, M.S.; Williams, D.W. Effects of Commercial Diazinon and Imidacloprid on Microbial Urease Activity in Soil and Sod. J. Environ. Qual. 2005, 34, 1573. [CrossRef]

114. Colores, G.M.; Schmidt, S.K. Recovery of Microbially Mediated Processes in Soil Augmented with A Pentachlorophenol-Mineralizing Bacterium. Environ. Toxicol. Chem. 2005, 24, 1912. [CrossRef]

115. Mayanglambam, T.; Vig, K.; Singh, D.K. Quinalphos Persistence and Leaching Under Field Conditions and Effects of Residues on Dehydrogenase and Alkaline Phosphomonoesterases Activities in Soil. Bull. Environ. Contam. Toxicol. 2005, 75, 1067-1076. [CrossRef] 
116. Qian, H.; Hu, B.; Wang, Z.; Xu, X.; Hong, T. Effects of validamycin on some enzymatic activities in soil. Environ. Monit. Assess. 2007, 125, 1-8. [CrossRef]

117. Enserink, M.; Hines, P.J.; Vignieri, S.N.; Wigginton, N.S.; Yeston, J.S. The pesticide paradox. Science 2013, 341, 728-729. [CrossRef]

118. Owen, M.D.K.; Beckie, H.J.; Leeson, J.Y.; Norsworthy, J.K.; Steckel, L.E. Integrated pest management and weed management in the United States and Canada. Pest Manag. Sci. 2015, 71, 357-376. [CrossRef]

119. Lacey, L.A.; Georgis, R. Entomopathogenic nematodes for control of insect pests above and below ground with comments on commercial production. J. Nematol. 2012, 44, 218.

120. Gupta, S.; Dikshit, A.K. Biopesticides: An ecofriendly approach for pest control. J. Biopestic. 2010, 3, 186.

121. Meena, A.K.; Meena, A.K. Characterization and antagonistic effect of isolated Trichoderma sp. against pathogens under Clusterbean (Cyamopsis tetragonoloba L.). Indian J. Agric. Res. 2016, 50, 249-253. [CrossRef]

122. Alam, G.; Alam, G. A Study of Biopesticides and Biofertilisers in Haryana, India; International Institute for Environment and Development: London, UK, 2000.

123. Sharma, M.P.; Sharma, A.N.; Hussaini, S.S. Entomopathogenic nematodes, a potential microbial biopesticide: Mass production and commercialisation status-A mini review. Arch. Phytopathol. Plant Prot. 2011, 44, 855-870. [CrossRef]

124. Neal, A.L.; Ahmad, S.; Gordon-Weeks, R.; Ton, J. Benzoxazinoids in Root Exudates of Maize Attract Pseudomonas putida to the Rhizosphere. PLOS ONE 2012, 7, e35498. [CrossRef]

125. Akiyama, K.; Hayashi, H. Strigolactones: Chemical signals for fungal symbionts and parasitic weeds in plant roots. Ann. Bot. 2006, 97, 925-931. [CrossRef]

126. Broughton, W.J.; Zhang, F.; Perret, X.; Staehelin, C. Signals exchanged between legumes and Rhizobium: Agricultural uses and perspectives. Plant Soil 2003, 252, 129-137. [CrossRef]

127. Pathan, S.I.; Větrovský, T.; Giagnoni, L.; Datta, R.; Baldrian, P.; Nannipieri, P.; Renella, G. Microbial expression profiles in the rhizosphere of two maize lines differing in $\mathrm{N}$ use efficiency. Plant Soil 2018, 433, 401-413. [CrossRef]

128. Gupta Sood, S. Chemotactic response of plant-growth-promoting bacteria towards roots of vesicular-arbuscular mycorrhizal tomato plants. FEMS Microbiol. Ecol. 2003, 45, 219-227. [CrossRef]

129. Gopal, M.; Gupta, A.; Arunachalam, V.; Magu, S.P. Impact of azadirachtin, an insecticidal allelochemical from neem on soil microflora, enzyme and respiratory activities. Bioresour. Technol. 2007, 98, 3154-3158. [CrossRef]

130. Govindachari, T.R.; Suresh, G.; Gopalakrishnan, G.; Masilamani, S.; Banumathi, B. Antifungal activity of some tetranortriterpenoids. Fitoterapia 2000, 71, 317-320. [CrossRef]

131. Coventry, E.; Allan, E.J. Microbiological and Chemical Analysis of Neem (Azadirachta indica) Extracts: New Data on Antimicrobial Activity. Phytoparasitica 2001, 29, 441-450. [CrossRef]

132. Elnasikh, M.H.; Osman, A.G.; Sherif, A.M. Impact of neem seed cake on soil microflora and some soil properties. J. Sc. Tech. 2011, 12, 144-150.

133. Xu, X.; Chen, C.; Zhang, Z.; Sun, Z.; Chen, Y.; Jiang, J.; Shen, Z. The influence of environmental factors on communities of arbuscular mycorrhizal fungi associated with Chenopodium ambrosioides revealed by MiSeq sequencing investigation. Sci. Rep. 2017, 7, 45134. [CrossRef]

134. Lu, F.C.; Lee, C.Y.; Wang, C.L. The influence of arbuscular mycorrhizal fungi inoculation on yam (Dioscorea spp.) tuber weights and secondary metabolite content. PeerJ 2015, 3, e1266. [CrossRef]

135. Kiran, U.; Patra, D.D. Medicinal and aromatic plant materials as nitrification inhibitors for augmenting yield and nitrogen uptake of Japanese mint (Mentha arvensis L. Var. Piperascens). Bioresour. Technol. 2003, 86, 267-276. [CrossRef]

136. Mohanty, S.; Patra, A.K.; Chhonkar, P.K. Neem (Azadirachta indica) seed kernel powder retards urease and nitrification activities in different soils at contrasting moisture and temperature regimes. Bioresour. Technol. 2008, 99, 894-899. [CrossRef]

137. Medina, M.J.H.; Gagnon, H.; Piché, Y.; Ocampo, J.A.; Garrido, J.M.G.; Vierheilig, H. Root colonization by arbuscular mycorrhizal fungi is affected by the salicylic acid content of the plant. Plant Sci. 2003, 164, 993-998. [CrossRef]

138. Tilak, K.; Ranganayaki, N.; Pal, K.; De, R.; Saxena, A.K.; Nautiyal, C.S.; Mittal, S.; Tripathi, A.K.; Johri, B.N. Diversity of plant growth and soil health supporting bacteria. Curr. Sci. 2005, 136-150.

139. Sethi, S.; Gupta, S. Impact of Pesticides and Biopesticides on Soil Microbial Biomass Carbon. Univers. J. Environ. Res. Technol. 2013, 3, 2. 
140. Tripathi, A.K.; Mishra, S. Plant Monoterpenoids (Prospective Pesticides). In Ecofriendly Pest Management for Food Security; Academic Press: Cambridge, MA, USA, 2016; pp. 507-524.

141. Tan, S.; Chen, X.; Li, D. Progress in the studies on Helicoverpa spp. resistance to transgenic Bt cotton and its management strategy. Kun Chong Xue Bao Acta Entomol. Sin. 2002, 45, 138-144.

142. Sessitsch, A.; Kan, F.Y.; Pfeifer, U. Diversity and community structure of culturable Bacillus spp. populations in the rhizospheres of transgenic potatoes expressing the lytic peptide cecropin B. Appl. Soil Ecol. 2003, 22, 149-158. [CrossRef]

143. Liu, B.; Zeng, Q.; Yan, F.; Xu, H.; Xu, C. Effects of transgenic plants on soil microorganisms. Plant Soil 2005, 271, 1-13. [CrossRef]

144. Mishra, P.K.; Ekielski, A.; Mukherjee, S.; Sahu, S.; Chowdhury, S.; Mishra, M.; Talegaonkar, S.; Siddiqui, L.; Mishra, H. Wood-Based Cellulose Nanofibrils: Haemocompatibility and Impact on the Development and Behaviour of Drosophila melanogaster. Biomolecules 2019, 9, 363. [CrossRef]

145. Heuer, H.; Kroppenstedt, R.M.; Lottmann, J.; Berg, G.; Smalla, K. Effects of T4 Lysozyme Release from Transgenic Potato Roots on Bacterial Rhizosphere Communities Are Negligible Relative to Natural Factors. Appl. Environ. Microbiol. 2002, 68, 1325-1335. [CrossRef]

146. Schmalenberger, A.; Tebbe, C.C. Genetic profiling of noncultivated bacteria from the rhizospheres of sugar beet (Beta vulgaris) reveal field and annual variability but no effect of a transgenic herbicide resistance. Can. J. Microbiol. 2003, 49, 1-8. [CrossRef]

(C) 2020 by the authors. Licensee MDPI, Basel, Switzerland. This article is an open access article distributed under the terms and conditions of the Creative Commons Attribution (CC BY) license (http://creativecommons.org/licenses/by/4.0/). 